\title{
Archipel
}

A RCHIPEL Études interdisciplinaires sur le monde insulindien

$102 \mid 2021$

Varia

\section{Alorese Textiles, specifically Tenapi, and their Production of Ternate Island, Alor Regency, NTT, Indonesia}

Textiles alorais, en particulier le tenapi, et leur production sur l'île de Ternate, district d'Alor, NTT, Indonésie

Linda S. McIntosh et Yulianti A. Peni

\section{OpenEdition}

Journals

Édition électronique

URL : https://journals.openedition.org/archipel/2667

DOI : 10.4000/archipel.2667

ISSN : 2104-3655

Éditeur

Association Archipel

\section{Édition imprimée}

Date de publication : 31 December 2021

Pagination : 209-239

ISBN : 978-2-910513-87-0

ISSN : 0044-8613

\section{Référence électronique}

Linda S. McIntosh et Yulianti A. Peni, «Alorese Textiles, specifically Tenapi, and their Production of Ternate Island, Alor Regency, NTT, Indonesia », Archipel [En ligne], 102 | 2021, mis en ligne le 15 décembre 2021, consulté le 15 décembre 2021. URL : http://journals.openedition.org/archipel/2667 ; DOI : https://doi.org/10.4000/archipel.2667 
Linda S. MCINTOSH* AND YULIANTI A. PENI **

\section{Alorese Textiles, specifically Tenapi, and their Production of Ternate Island, Alor Regency, NTT, Indonesia}

Research and publications on the material culture of the Alorese of Alor Regency, NTT, Indonesia, is scarce, and a study of their textile production is absent from the field of Indonesian textiles. Ernst Vatter (1932: 241-244) described some weaving of the Alor Archipelago in his publication describing the cultures of this region but gave little detail, especially concerning the warp ikat textiles produced in the islands of present-day Alor Regency. Cora DuBois (1944) studied the Abui culture of Central Alor and remarked that this group made bark cloth since a "prohibition" against weaving in the hinterland existed and affluent Abui acquired woven materials from various textileproducing coastal settlements of the archipelago. Khan Majis (1991: 213) wrote in an exhibition catalogue that "textiles from the islands of Pantar Alor were virtually unknown until now." Roy W. Hamilton (2010: 304) remarked on the "almost total absence" of textiles from the island of Alor in publications about Indonesian textiles and suggested that handwoven fabrics originated from other islands or were produced by people who came from afar if made in the archipelago. Books devoted to Indonesian and Southeast Asian weavings briefly mention the textiles from the Alor Archipelago. For example, Michael C. Howard (2010: 63) devoted two paragraphs to some examples produced in the Alor Archipelago in his survey of ikat-decorated cloth of Southeast Asia. Howard (2008: 45) also remarked about the lack of documentation on the textiles from this area in his survey of warp float-decorated textiles.

\footnotetext{
* Independent Scholar and Research Associate of Tracing Patterns Foundation, USA. ** Curator 10,000 Moko Museum, Kalabahi, Alor Regency, NTT, Indonesia.
} 


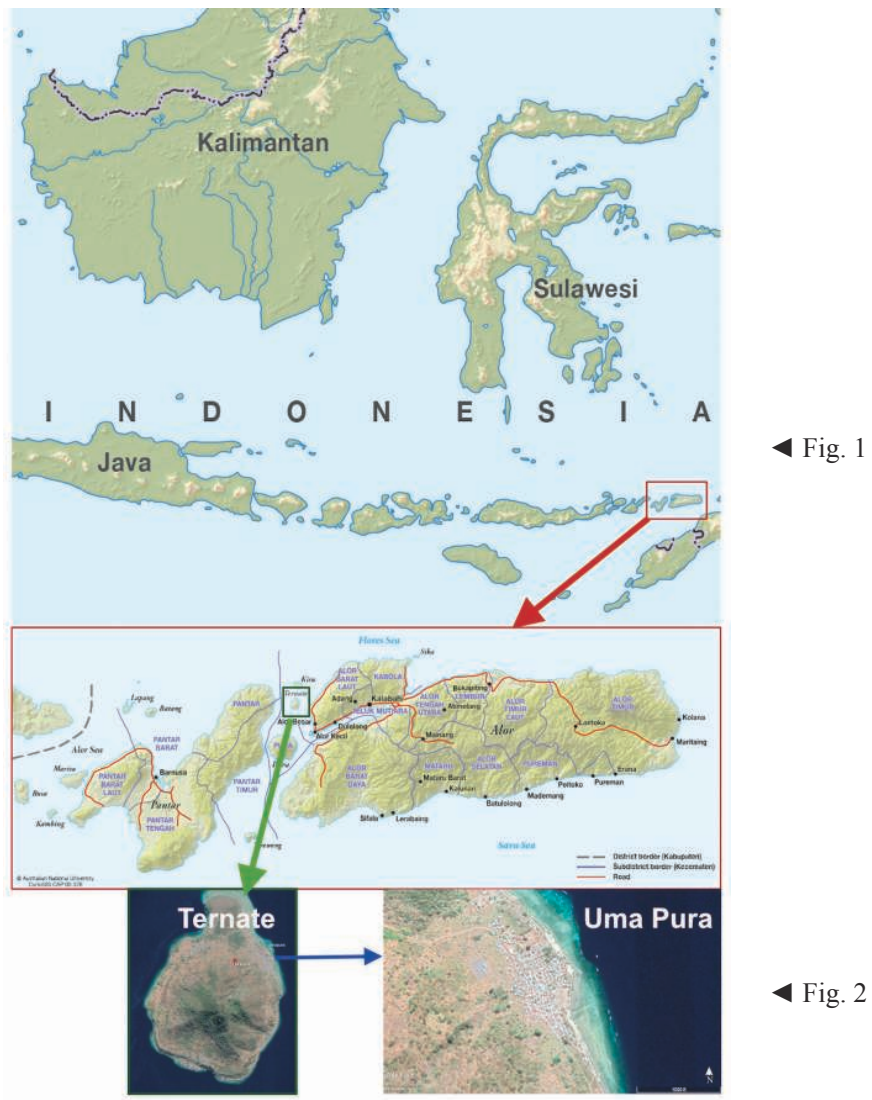

Figs. 1-2 - Localization and maps of Ternate Island (Alor Regency, Nusa Tenggara Timur Province, Indonesia) and Uma Pura Hamlet (Ternate Selatan or South Ternate village, Alor Barat Laut or Northwest Alor district).(Google Earth, https://earth.google.com/web/)

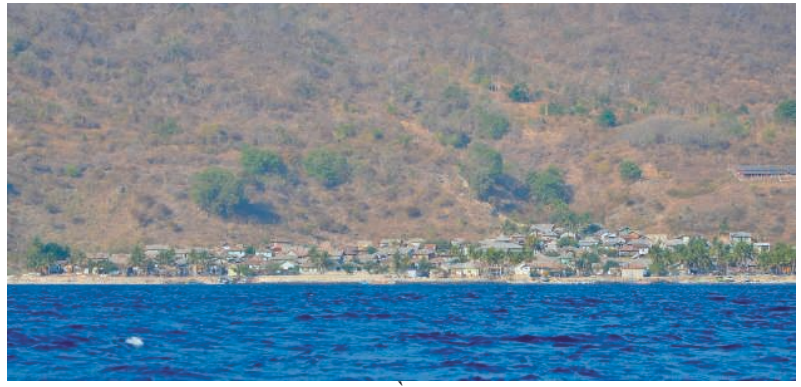

Fig. 3 - Arriving in Uma Pura Village, Ternate Island, by boat from Alor Island (Photography: Linda S. McIntosh).

Emilie Wellfelt (2014) explored the use of milkweed fibre as a thread by the Alorese and the trade relations between the Alorese villagers of Uma Pura 
Hamlet in Desa (village) Ternate Selatan on Ternate Island (a small island between Pantar island and Alor island) and other ethnic groups in the Solor and Alor archipelagos. Two publications highlighting a private collection of Indonesian ikat textiles feature some Alorese examples. The first was an exhibit catalogue that featured two tubular garments to illustrate Alor Regency's warp ikat traditions (ten Hoopen 2014: 33-34). The number of textiles representing this regency increased to three in the second book on the Pusaka Collection (ten Hoopen 2018: 381-384). The information about these published textiles was not acquired during field research but via third parties. Recently, We (2020) published an article on the characteristics of ceremonial garments of Uma Pura, Alor Regency. We also produced an e-book, Textiles of Alor, as an introduction to the different textile traditions of the regency, including Alorese textiles, and a website, www.alortextiles.org, since the central government funding to print the book was used instead as emergency assistance during the 2020 pandemic (McIntosh and Peni 2020). Another website, asiantextilestudies.com, authored by David and Sue Richardson who are textile tour guides and textile collectors describes Alorese textiles of Buaya island and natural dyeing of Ternate island of Alor Regency.

Research concerning the people from Alor Regency, including the Alorese, has focused on history, linguistics, and kinship or other alliances. Recent studies on the languages of the Alor Archipelago, such as the Reconstructing the Past through Languages of the Present: The Lesser Sunda Islands Project (20142019) of Leiden University led by linguist Marian Klamer, have provided a clearer understanding of the Alorese, or the sole Austronesian language to have evolved in this group of islands and its relation to the Lamaholot languages and non-Austronesian Alor-Pantar languages (Kaiping, Edwards, and Klamer 2019). Both Alorese and Lamaholot belong to the same sub-branch in the Austronesian ethnolinguistic family, but they are distinct languages with 50-60 per cent mutual intelligibility (Klamer, 2011:24). Alorese is the sole indigenous Austronesian language spoken in the Alor Archipelago. The remaining two dozen languages and dialects belong to the Alor-Pantar branch of the TransNew Guinea ethnolinguistic family (Klamer 2012: 74-75).

This article explores tenapi, a ceremonial tubular garment used to differentiate members of one patrilineal clan from another and textile production, including natural dyeing, of the Alorese people of Uma Pura, Desa (Village) Ternate Selatan, Kecamatan (District) Alor Barat Laut, Kabupaten (Regency) Alor, Nusa Tenggara Timur, Indonesia (fig. 1-2). It also addresses changes in contemporary production due to external factors such as various government programs seeking to promote handweaving. A decline in the number of weavers that can produce such garments has occurred since many women have focused their efforts on creating other types of textiles that meet the demands of an expanded and diverse market. The changes will be discussed later in the article. 
Alorese tenapi or tubular skirts resemble garments produced by other cultures found in eastern Indonesia, including those made by Lamaholot weavers in the neighbouring island of Lembata. Similarities include cotton as the primary material and warp ikat resist dye technique as the main decorative technique. Contact due to proximity, trade, and intermarriage occurred between these communities, and exposure to the textiles of the two related cultures likely occurred. Cloth serving as bridewealth in Lamalera, Lembata Regency, consists of three panels with the midsection decorated with patterning inspired by Indian patola are similar to the tenapi representing the ruling lineage of Uma Pura (Barnes 1989: 51, 60). However, the precise design formats of these tubular garments of the two cultures differ, and the symbolism of the motifs diverge. Also, no prohibition in Uma Pura exists against the use of synthetic dyed thread purchased in the market for ceremonial garments in contrast with Lamaholot communities of Lamalera, Lembata Regency (Barnes 1989: 46-47).

Indigo, morinda, turmeric, and sappan wood are some of the dyes used by the Alorese and other ethnic groups in Indonesia. Alorese weavers of Uma Pura also apply marine life ingredients to colour threads, a distinct characteristic of their textile production. The Alorese have developed distinctive markers of ethnic affiliation and patrilineal clan membership by using a combination of plant and marine life dyes, motifs, different-coloured stripes, and design formats consisting of various-sized warp ikat rows to differentiate their textiles from other cultural groups in the Alor Archipelago and other regions of Indonesia. Cloth woven by non-Austronesian Alor-Pantar groups of the Alor Archipelago is not decorated with warp ikat but with different techniques such as complementary and supplementary warp and slit-tapestry (McIntosh and Peni 2020).

Alorese textiles and the steps involved in their production are significant and worthy of preservation before the information is lost as textile production changes to meet non-traditional consumer demand. The quality of the warp ikat patterning and design format and the colours of Alorese textiles are modified as new markets such as Indonesian fashion designers in Jakarta, domestic and international tourists, and students and government officials of the regency demand different colour schemes and rapid output. The colours and design format of ceremonial attire worn to represent membership in a specific clan have not altered. However, the future of these adat or ritual garments is under threat since the diversification and commercialisation of textile production results in less time available to focus on weaving tenapi for ritual use. Documenting the textiles of Uma Pura will also hopefully contribute to a better understanding of Indonesian textiles and material culture. The field research occurred from 2018 until 2021 for a cumulative total of four months. It consisted of non-formal interviews, non-participant observation including witnessing different steps of the dyeing and weaving processes and festivals, the examination of textiles, and virtual meetings. Co-author Peni is in regular contact with the weavers of Uma Pura in her capacity as a curator of the 
Museum 1000 Moko of Kalabahi, the capital of Alor Regency, from 2014 until the present, and documentation by both authors is ongoing.

\section{Background}

Alorese (or Alurung) comprise the population of Uma Pura, Desa Ternate Selatan, Northwest Alor District of Alor Regency. Members of this group also live in the coastal areas of Buaya, Pantar and Alor islands. Fricke and Klamer (2018) conclude that the ancestors of the Alorese people migrated west from Lembata to Adonara and Solor, or islands composing the Solor Archipelago, before moving east and settling in the coastal areas of West and North Pantar and Northwest Alor islands by the beginning of the fourteenth century. The people of Uma Pura Village on Ternate island state their ancestors originated from neighbouring Pura Island. McIntosh and Peni summarise Uma Pura's origin story described by Wellfelt (2007: 39) as follows:

A war between two villages on Pura led to the razing of their homes. The Bungabali ruler offered them refuge, and they resettled in Northwest Alor and, later, in present-day Sebanjar Village on the coast. They established Uma Pura or "House of Pura" when they moved from Sebanjar to present-day Ternate that the settlers called the Nuha Being or "Big Island."

Uma Pura is on the northeast coast of Pulau Ternate or Ternate island located in the Pantar Strait off the southwest coast of the Bird's Head Peninsula of Alor Island (fig. 3). Uma Pura is the sole Alorese settlement on the island, and the island's other communities speak a non-Austronesian language called Reta from the Alor-Pantar branch of the Trans-New Guinea ethnolinguistic family. Uma Pura is part of Desa Ternate Selatan, and the population of Ternate Selatan in 2019 was 861 (Central Bureau of Statistics of Alor Regency 2020:15).

Uma Pura society organises into the patrilineal clans or suku. Suku clans are also referred to as uma or "houses." Members of a uma or suku identify with the same founding father of a patrilineage. Wellfelt (2007: 19-20) stresses that membership in one of these lineages or houses is essential to individual and group social identity. Some of Uma Pura's population moved to nearby Buaya island in the 1930s because of a disagreement regarding which sect of Islam to follow (Gomang 1993: 114). The eight patrilineal lineages of Uma Pura and Buaya are: Suku Uma Kakang; Suku Uma Tukang; Suku Uma Aring; Suku Uma Wilawalu Atas; Suku Uma Wilawalu Bawah; Suku Uma Denwahi; Suku Uma Folang Klelang; and Suku Uma Biatabang.

Affiliation in one of these patrilineal clans is reflected in the design format, the combination of different-coloured stripes, and motifs of specific types of tubular skirts or tenapi that women of Uma Pura continue to weave. Kafate is the word used for a tubular garment in general, and tenapi refers to specific types of skirts, according to the weaver informants, and Wellfelt (2014: 4) recorded that these terms are interchangeable but uses tenapi when naming a specific type of 
tubular garment. Kafate is similar to kewatek, or the name for a tubular garment in some Lamaholot dialects. Ruth Barnes (2004) recorded the terms for this garment as kafatek or kefatek in Lamalera, South Lembata, as kafatek or kefatek and kewatek in Lerek, Southeast Lembata. The consonant "w" in the Western Alorese dialect spoken by the Alorese residing in West Pantar is replaced by " $\mathrm{f}$ " in the Eastern Alorese dialect spoken in Northwest Alor District, including Uma Pura. Some Alorese vocabulary ends with an open syllable or vowel, and thus, kafatek becomes kafate or kefate in East Alorese dialect and kewate in West Alorese dialect (Fricke and Klamer 2018: 6; Klamer 2011: 25-32). Most Uma Pura villagers continue to wear tenapi (or kafate) symbolising their membership in one of the eight patrilineal lineages for important ceremonies. These garments also serve as shrouds or covers of the deceased.

\section{Textile Production}

Women from all Uma Pura's patrilineal clans are responsible for all the steps of textile production and dyeing. Weaver informants describe that they previously cultivated cotton and some natural dyestuffs, including morinda and indigo, but the shortage of fresh water and arable land on Ternate Island of Alor Regency made it challenging to grow sufficient quantities. The lack of arable land for farming also led women of Uma Pura to specialise in weaving for trade. The cultivation of cotton and some natural dyestuffs primarily occurs near the hamlet of Sebanjar, Northwest District, Alor Island. The weavers state that indigo also grew wild on Ternate in the past, and other dyestuffs, such as milkweed and some types of trees, continue to grow freely in Ternate and Alor. They also acquire dyestuff ingredients from other islands via trade. Sappan wood is available from Southwest Alor and Pantar, while alum-rich symplocos leaves come from Pantar Island. The islands of Lembata, Flores and Timor were the source of additional cotton (Gomang 1993: 107). Some weavers described growing cotton as sufficient for just one garment in a year in the past, but the annual supply of cotton was often not enough for a single garment leading to buying cotton from other communities in Alor or other islands. Weavers or sailors exchanged earthenware pots from Northwest Alor for the raw material, and the price of a vessel was equal to the amount of unspun cotton that could fill it (Barnes 1989: 253).

Weavers also spin the floss of the milkweed pod (Calotropis gigantea) to create a silk-like yarn when spun with cotton. As stated previously, the process rarely occurs today since the process is difficult and less handspun is produced in the area (Wellfelt 2014: 8-9) (fig. 4). A variety of synthetic, silk-like yarns is available in the local market, and weavers prefer to use these threads rather than spinning cotton or milkweed floss with cotton presently.

The cultivation of cotton, hand spinning, and natural dyeing continue in Uma Pura. The creation of handspun cotton thread in Uma Pura resembles the process carried out in other parts of Indonesia. Women clean the raw material 
before ginning the seeds from the bolls. Then, they beat or card the ginned cotton to remove dust and even out the cotton fibres. The next step is to roll the carded cotton into rolags. Weavers stated they use both the spinning wheel and drop spindle for producing thread. The authors observed weavers spinning on a wheel but did not see a drop spindle in use for cotton (fig. 5), but women rely on the drop spindle to combine milkweed fibre and raw cotton into a yarn (see fig. 4). One oral story describes a spinning wheel as one of the gifts the imams or teachers of Islam brought to the Alor Archipelago, and some interpret the spinning wheel as the introduction of the knowledge of weaving to the region and as one of the "civilising" effects of the religion (Rodemeier 2010: 33).

Textile production occurs on a backstrap or body-tension looms using a circular warp, which is widespread in eastern Indonesia (fig. 6). Warp ikat or resist dye is the primary decorative technique, another trait that Alorese textiles share with weavings produced in other areas of this region (fig. 7). Uma Pura weavers also utilise complementary warp, a technique preferred by members of different ethnic groups living along the south and east coasts of Alor Island, to decorate textiles to sell in the local markets (McIntosh and Peni, 2020). Alorese women supplied their non-weaving neighbours with cloth in the past and continue this activity in the twenty-first century.

Mama Sahari Kamarin of the Pante Laut Weaver's Cooperative recounted a story about the symbolism of spinning cotton in the Indonesian language on May 22, 2018, and October 24, 2019, in Uma Pura: The act of spinning cotton on a spinning wheel re-enacts pro-creation and the establishment of Uma Pura's eight clans. The two posts holding the wheel are the founding father and mother of Uma Pura (these posts are compared to house pillars). The act of winding a spinning wheel's handle and the movement of the driver band or thread around the wheel, tenu'e tale, to the pisi or flyer whorl symbolizes reproduction. As a weaver turns the wheel to spin raw cotton into thread, the ball of cotton thread winding onto the spool swells like a woman's belly during pregnancy. The community considers fabric woven from this handspun cotton thread as the offspring of the founding parents of Uma Pura's eight patrilineal lineages. Cotton fabric is a product of the earth and the weaver who is female, signifying fertility. Spinning cotton, thus, represents the act of reproduction.

\section{Tenapi of Uma Pura}

Warp ikat is one of the defining characteristics of the handwoven cloth of Uma Pura. Both men and women wear the tubular garment or tenapi. Men generally use this article of clothing for ceremonial occasions in the same method as women do or as a tubular garment (figs. 8 and 9), but some males wear it as a hip wrapper over trousers or another lower tubular garment. A tubular garment serves other roles such as a shroud of a deceased person, as a cover of new roof components just before being installed on a clan house, and as a blanket or accessory to keep warm in cool weather (fig. 10). Handwoven cloth 


\begin{tabular}{|c|c|}
\hline Suku or Patrilineage Name & Name of the Tenapi \\
\hline Suku Uma Kakang & Tenapi Fatola (Patola) Baololong \\
\hline Suku Uma Tukang & Tenapi Belang \\
& Tenapi Fadang \\
\hline Suku Uma Aring & $\begin{array}{c}\text { Tenapi Matang Karing } \\
\text { Tenapi Fadang }\end{array}$ \\
\hline Suku Uma Wiluwalu Bawah & Tenapi Builihing (Bui'lihing) \\
& Lanzia \\
\hline Suku Uma Wiluwalu Atas & Tenapi Builihing (Bui'lihing) \\
& Baololong \\
\hline Suku Uma Dengwahi & Tenapi Muko Tahakang \\
\hline Suku Uma Folang Klaelang & Tenapi Leor Manis \\
\hline Suku Uma Biatabang & Tenapi Sinta Gala \\
\hline
\end{tabular}

Table 1 - Tenapi or Ceremonial Tubular Garments of the Eight Suku or Patrilineages of Uma Pura Village, Desa Ternate Selatan, Alor Regency, NTT, Indonesia.

is also exchanged during marital rites. Examples of tenapi serve as payment to make amends for wrongdoing or to compensate persons who have helped to dig a grave or contributed items for funeral rites (Hägerdal 2011: 57-60).

A tubular garment is generally composed of two panels of cloth with the same patterning and design format, forming a mirror reflection in the horizontal axis. Other types of tubular garments consist of three panels in which the middle section of a three-panelled skirt contains a different format and patterning compared to outer parts. Mirror symmetry in the horizontal axis is maintained in a three-panelled cloth. A shawl composed of two pieces of fabric was also used in the past, but both men and women generally wear a single-panelled shoulder cloth presently. This narrow fabric also serves as a head covering or sash.

Specific types of tenapi represent the different patrilineal lineages of Uma Pura (Peni and McIntosh 2020) (see table 1). The weaver informants informed the authors that each garment type possesses a name that serves as the identifier of a specific tubular skirt and that the name does not symbolize anything. Other types of tenapi are clan neutral or do not designate affiliation in a patrilineage. These lower garments are also named to indicate the design format and motifs that decorate it.

The tenapi patola bao lolong signifies membership in the ruling patrilineage or Suku Uma Kakang (fig. 11). The different communities of Alor and Pantar islands placed a high value on imported patola or double ikat silk textiles woven in India that other cultures of present-day Indonesia also coveted (Gomang 1993: 107-108; Hägerdal 2010: 227). Members of the ruling clans held the prerogative to own these prestige goods that became sacred heirlooms. The lattice designs adorning some types of patola are echoed in the motifs filling the central panel of the three-panelled tenapi patola bao lolong worn by members of the Suku 
Uma Kakang or ruling patrilineage of Uma Pura. This motif also decorates the primary design row of each outer section of a tenapi patola bao lolong and is called bao lolong sambung (fig. 20b).

Members of the Suku Uma Tukang wear tenapi belang and tenapi fadang. Bold white and orange stripes identify the two-panelled tenapi belang, and the largest warp ikat row is located near the top and bottom ends of a garment (fig. 12). The distinguishing markers of the two-panelled tenapi fadang are the presence of green and blue stripes flanking rows of narrow warp ikat dashes that are found between the primary bands of warp ikat patterning (fig. 13). Suku Uma Aring members utilise tenapi matang karing and tenapi fadang as lineage markers (fig. 14). The tenapi matang karing, or "skirt of small eyes," is adorned with numerous rows of warp ikat dashes called broken fruit of the Piper betel vine (Piper betle, Alorese malu gilu). These dashes are also called peku-peku. Bright stripes, especially purple and pink, separate the warp ikat bands of a tenapi matang karing.

The tenapi bui'lihing lanzia represents the Wilawalu Bawah patrilineal lineage (fig. 15). A bui'lihing, also spelt builihing, consists of a middle section of solid stripes, narrow rows of warp ikat dashes, or a combination of both. A tenapi bui'lihing lanzia may be composed of two or three panels, and its peripheral sections each contain three different-sized warp ikat bands. The largest warp ikat row of the outer panels flanks the garment's middle section rather than its ends. A bold white stripe adorns one peripheral section of a tenapi bui'lihing lanzia, and a pink stripe decorates the other. Members of the clan called Suku Uma Wilawalu Atas utilise the tenapi bui'lihing bao lolong as a symbol of membership to this lineage (fig. 16). This tenapi type also contains stripes and narrow rows of warp ikat in its middle part, and the largest bands of warp ikat patterning decorating the outer panels contain the bao lolong or banyan tree leaf motif.

The tenapi muko tahakang of the Suku Uma Denwahi translates as "ripe banana skirt," named after the bright yellow stripe at each end and the groupings of yellow, orange, and green bands in the centre section (fig. 17). The tenapi leor manis represents the Folang Klelang patrilineage, while members of the Suku Uma Biatabang use the tenapi sinta gala as a marker of clan membership. Green stripes abut narrow bands of white warp ikat dashes in the middle of a tenapi leor manis, and this pattern refers to watermelon seeds (fig. 18). The tenapi sinta gala consists of a group of six orange stripes flanked by lighter-coloured stripes in between the largest bands of warp ikat designs (fig. 19).

\section{Warp Ikat Motifs}

The warp motifs symbolise items in the social and natural environment. Plants, sea life, and imported goods such as Chinese ceramics and Indian trade textiles inspired the motifs that decorate Alorese weavings (fig. 20). Informants state that a diamond shape represents the leaf of the banyan tree (Alorese bao - banyan; 
lolong - leaf) (fig. 20a), and a lattice composed of numerous diamond shapes is called bao lolong sambung or connecting banyan tree leaves (fig. 20b). The ritual centre (Alorese dolu) of a village consists of a mound of compacted earth and stones and generally with a banyan tree in its centre (fig. 21). Stone megaliths were also previously erected in some ritual circles (Gomang 1993: 20, 79; Rema and Prihatmoko 2016: 103-116). The government of the Alor Regency understood the importance of the dolu and a banyan tree in the cultures of the Alor Archipelago, and both symbols are part of the regency's emblem (Official Website of Alor Regency, accessed March 1, 2020). Baololong was the name of some rulers of Bungabali or Alor Besar, and an oral story describes the founder of Alor Kecil's ruling lineage sitting under a banyan tree (Gomang 1993: 29).

Designs based on the natural environment include the plinta or bursting kapok buds that signify the end of the dry season and the beginning of the rainy or farming season (fig. 20c). Chewing areca nut is a social activity in Alor, and dashes symbolise one of the ingredients for chewing areca nut or the broken piper betel vine fruit (Alorese malu gilu) (fig. 20d). Triangular shapes with a pair of radiating appendages represent the sea hare (Alorese ufe kotong) (fig. 20e). This motif is generally found at the end of the primary pattern row. A boat or nura (fig. 20f), coconut frond or tapo lolong (fig. 20g), tropical almond or utam pei (fig. 20h), and intertwining bodies or kago no-eking (fig. 20i) are other motifs adorning adat or traditional lower garments. Some weavers interpret the last design, kago no-eking as multiple bodies becoming one leading to harmony or solidarity in society.

Weavers create warp ikat designs of the mythical snake or ula naga that resemble dragon motifs decorating some Chinese ceramics that arrived in the Alor Archipelago as were trade items. These imported goods arrived in the archipelago directly via Chinese traders or indirectly via regional Indonesian sailors (Gomang 1993: 107; Hägerdal 2010: 233). Patterns of other snake motifs adorn some moko bronze or brass kettle drums that became sacred heirlooms and a traditional currency of the cultures of Alor (Andaya 2016: 66-89).

Beliefs in extraordinary serpents exist in some cultures of Alor such as the Adang and Alorese peoples. The ula naga, rulers of the forest, are part of some creation myths. For example, the first man and naga emerged from a hole in a creation story of the Adang group living alongside the Alorese. The Adang and Alurung continue to give offerings and ask the ula naga for advice and assistance at the Fet Lakatuil ceremonial house of the raja tanah or ruler of the land (Wellfelt 2016: 233-236). Images of these snakelike creatures occur as wood carvings and sculptures in Alorese settlements, such as the statues of ula naga guarding the entrance to the ruling lineage's ceremonial house and dolu of Alor Besar. A pair adorns Alor Kecil's ruling lineage's ceremonial meeting hall called Kokoro Labanhanji. The emblem of the ruling clan of Alor Besar or Bunga Bali consists of the bao lolong sambung and ula naga (Gomang 1993: 130). Variations of ula naga warp ikat designs occur on tenapi woven in Uma Pura. 


\section{Natural Dyeing}

Many weavers in Uma Pura Village continue to use natural dyestuffs. Morinda (morinda citrifolia, Alorese bota), joins indigo (Indigofera tinctoria and other varieties, Alorese taum) as the primary dyes. Turmeric (Curcuma longa, Alorese kumo) and cockspur thorn (Maclura cochinchinensis, Alorese akar) produce yellow shades. Sappan wood (Caesalpinia sappan, Alorese hong, song, or pen) creates a range of pinks and purples. Women use tannin-containing bark and heartwood from various trees such as Borneo teak (Intsia palembanica, Alorese ipi), Indian ash (Lannea coromandelica, Alorese bula), and jujube (Ziziphus mauritiana, Alorese kebuka) for an assortment of brown colours. Plants that grow profusely in Ternate, Buaya, and Alor, such as milkweed (Calotropis gigantea, Alorese keroko puho) and bellyache bush (Jatropha gossypiifolia, Alorese jarak merah), are other natural dyestuffs (fig. 22). The former creates light yellow to light green colours depending on the part of the plant used as the main ingredient, while the latter produces a beige to greenish-yellow dye.

Women used to cultivate some dye ingredients on Ternate Island, but they presently grow some dyestuffs and cotton on farmland opposite their villages on the island of Alor in the hamlet of Sabanjar. Some dyestuffs, such as sappan wood, are sourced and purchased from Southwest Alor and Pantar Island. Other ingredients that weavers purchase include alum-rich symplocos leaves (Symplocos cochinchinensis, Alorese loba lolong) from Pantar and candlenut (Aleurites moluccana, Alorese kamie) from both islands. Candlenut contains the oil mordant essential for forming a red-brown colour with morinda. Other additives used in Uma Pura Village are slaked lime powder or calcium hydroxide created from burning seashells, salt, and lime juice.

Weavers evaluate the intensity of a dye bath by the colour of the solution and the results when threads are dyed. They measure ingredients like a pinch, handful, heaping spoonful, or half a coconut shell-full. A batch of threads is repeatedly dyed until the desired shade of colour is achieved. Weavers wash the yarns with a small amount of detergent before immersing them in a dye vat and repeat this action before every subsequent round of dyeing. Some dye vats are heated, but cool water is used when dyeing with indigo, morinda, and marine life.

Additional colours are created by over-dyeing or sequentially dyeing threads in different vats or submerging materials in one type of dyebath and then in another. For example, indigo-dyed cotton fibres are later dyed with sappan wood to create a purple colour, and threads first dyed with turmeric and then dyed with indigo turns the yarns green. Some weavers use the remains of several vats together to create a mixed (Alorese, gau fe' $k i$ ) dye. 


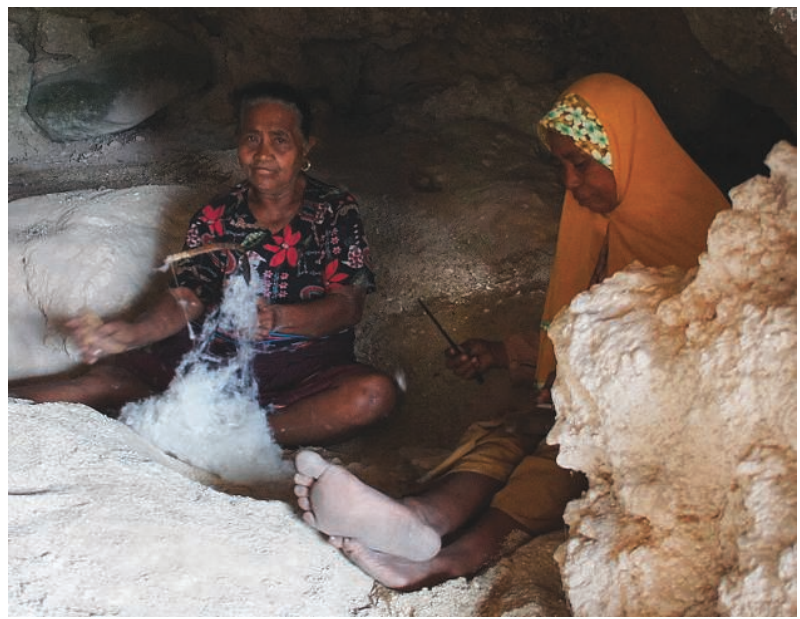

Fig. 4 - Weavers carry out the steps of combining milkweed floss and cotton, outskirts of Uma Pura. These steps are performed in a cave to prevent wind from blowing the milkweed floss, a light material, away. The raw cotton and milkweed fibres are carded together before spun into thread using a drop spindle. Photo by Gayle Roehm.
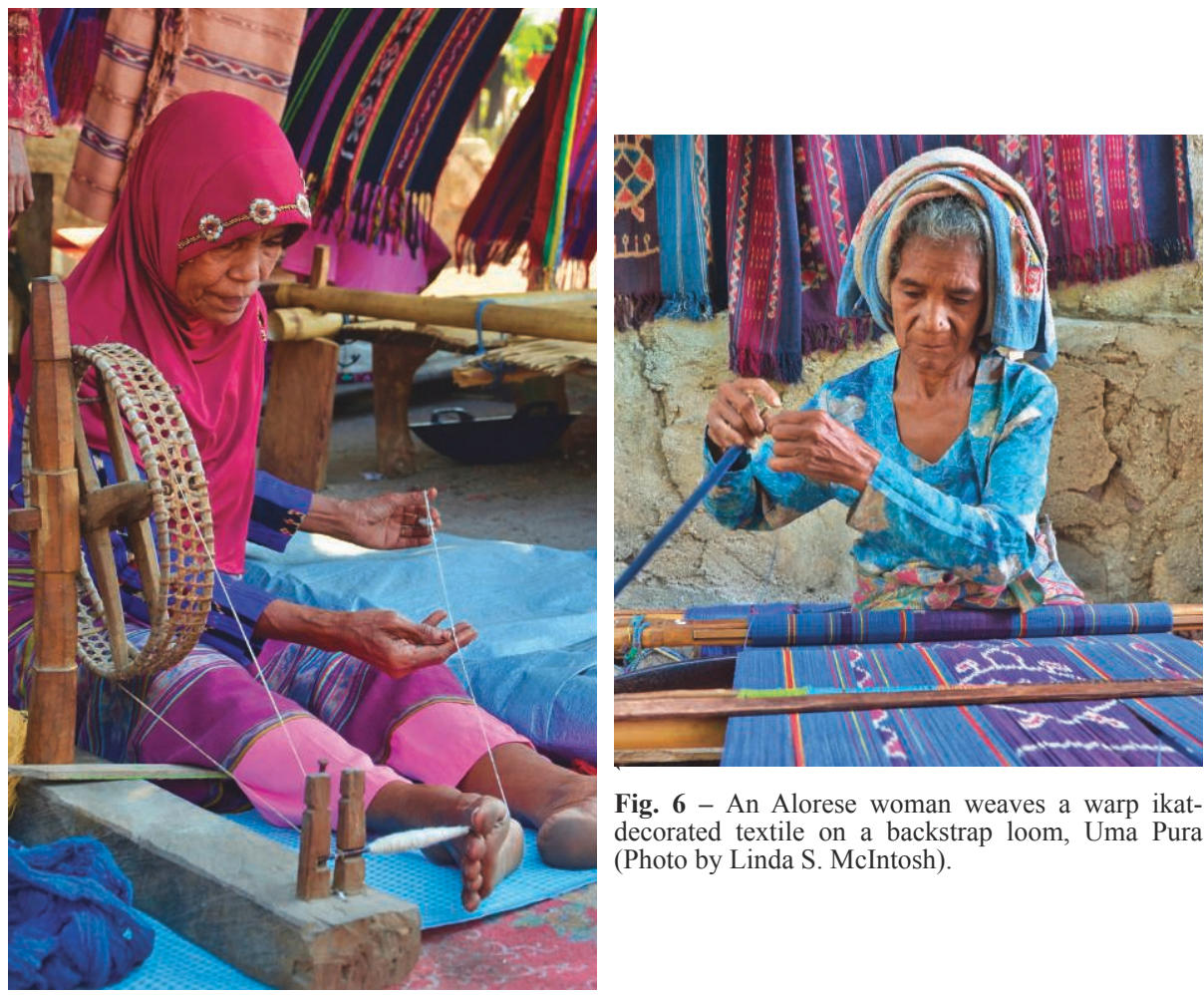

Fig. 6 - An Alorese woman weaves a warp ikatdecorated textile on a backstrap loom, Uma Pura (Photo by Linda S. McIntosh).

Fig. 5 - A weaver using a spinning wheel to form cotton thread in Uma Pura (Photo by Linda S. McIntosh). 


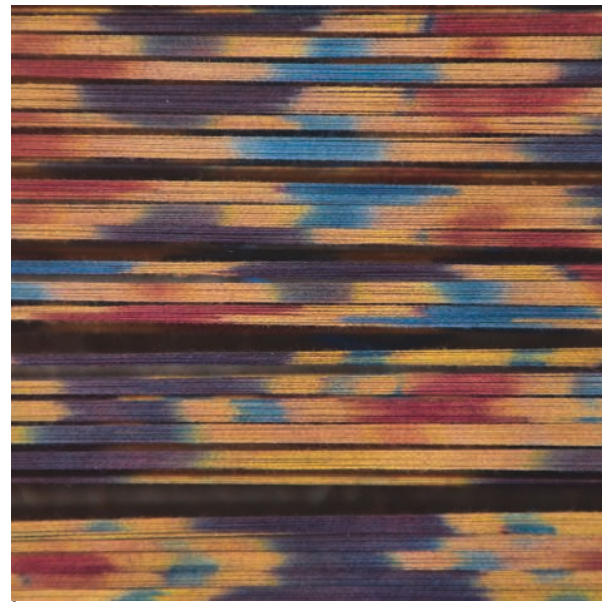

Fig. 7 - Warp ikat-decorated cotton threads before being woven into cloth, Uma Pura(Photo by Linda S. McIntosh).

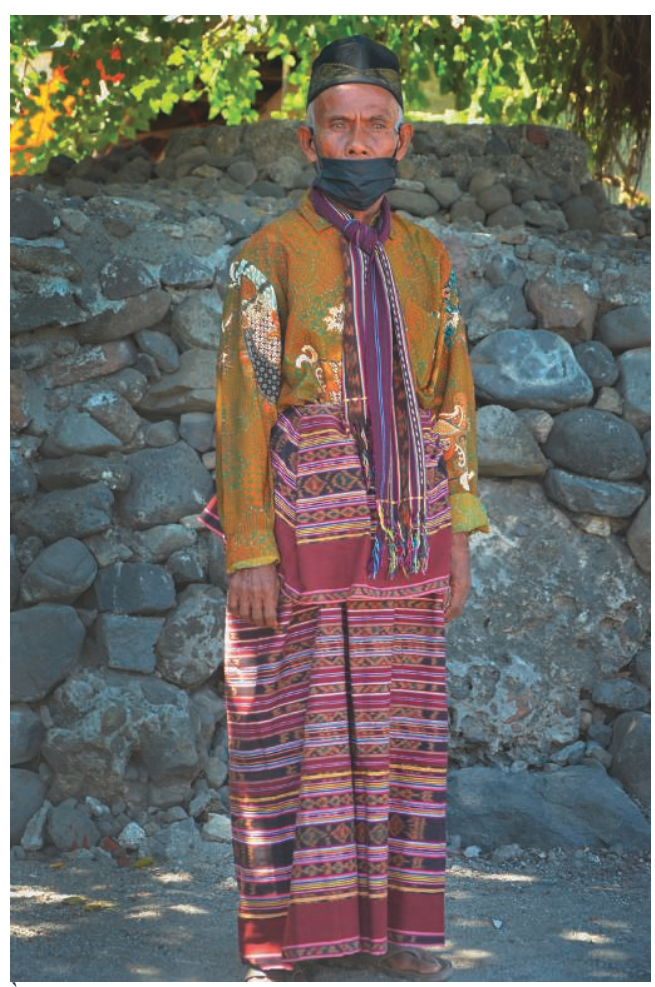

Fig. 8 - An Alorese male in a tenapi tubular garment, Northwest Alor Subdistrict (Photo by Yulianti Peni). 


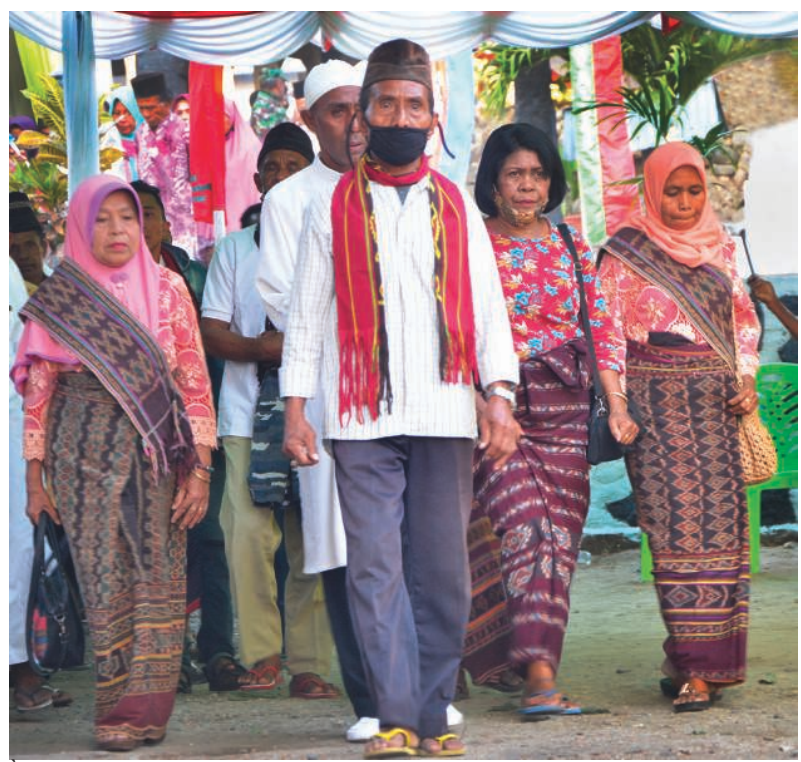

Fig. 9 - Women wearing tubular garments signifying patrilineal membership. The women standing on the left and far right are wearing tenapi patola bao lolong sambung (Photo by Yulianti Peni).

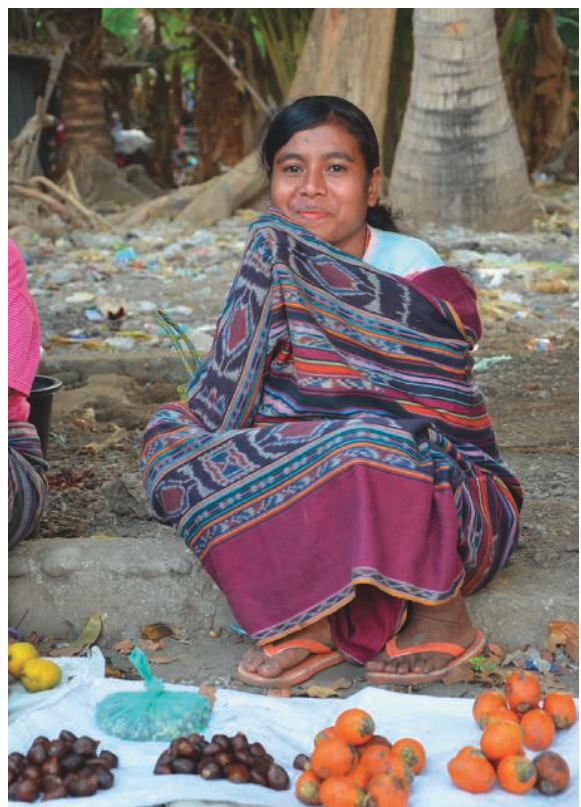

Fig 10 - A young woman utilises a warp ikatdecorated tubular garment as a cover to stay warm in the early morning hours. Baolong weekly market on coastal Northwest Alor Island opposite Uma Pura (Photo by Linda S. McIntosh). 


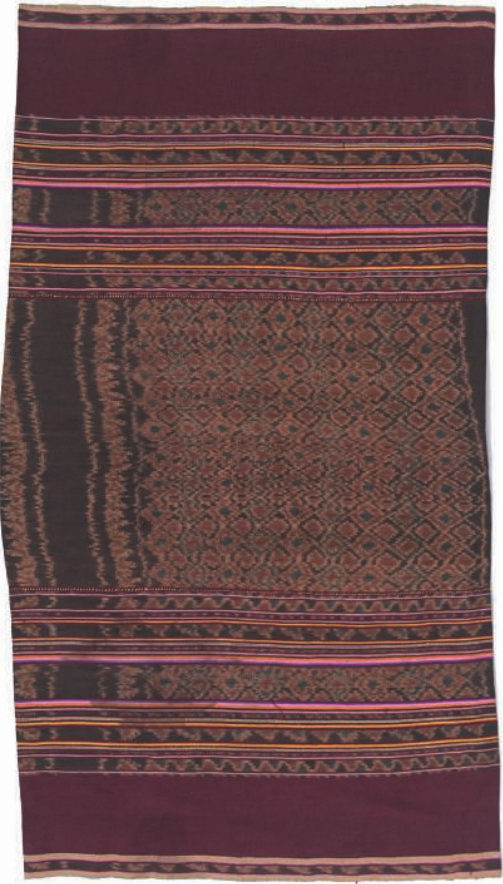

Fig 11 - Tenapi Patola Bao Lolong of the Suku Uma Kakang, Uma Pura (Photo by Linda S. McIntosh).

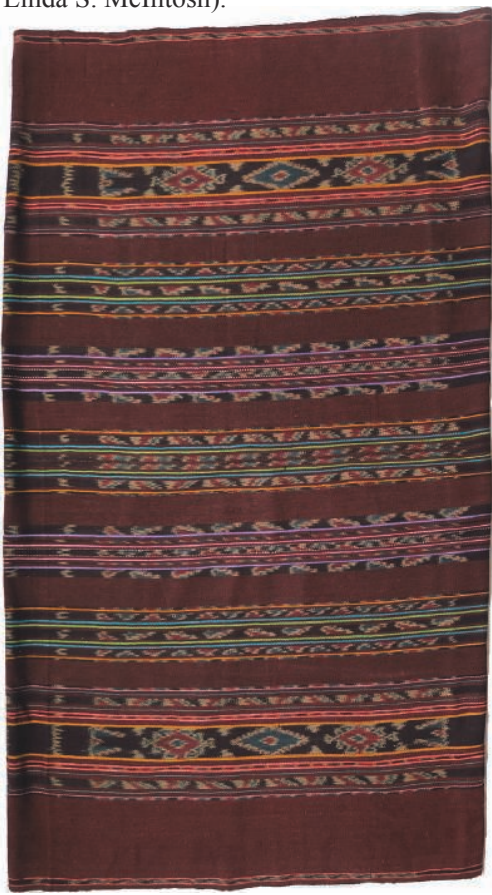

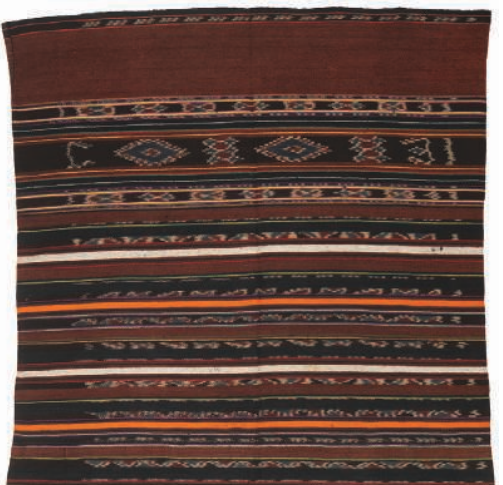
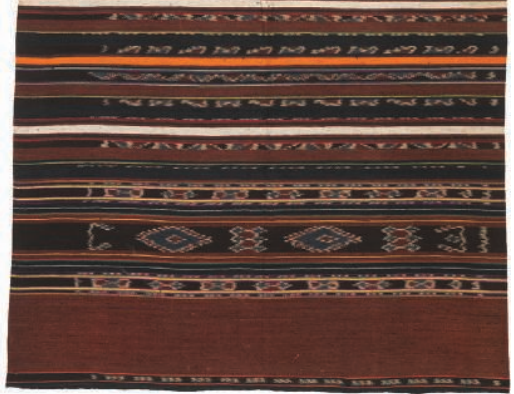

Fig 12 - Tenapi Belang of the Suku Uma Tukang, Uma Pura (Photo by Linda S. McIntosh).

Fig 13 - Tenapi Fadang of the Suku Uma Tukang and Suku Uma Aring, Uma Pura. Collection of Aja Bordeville (Photo by Aja Bordeville). 


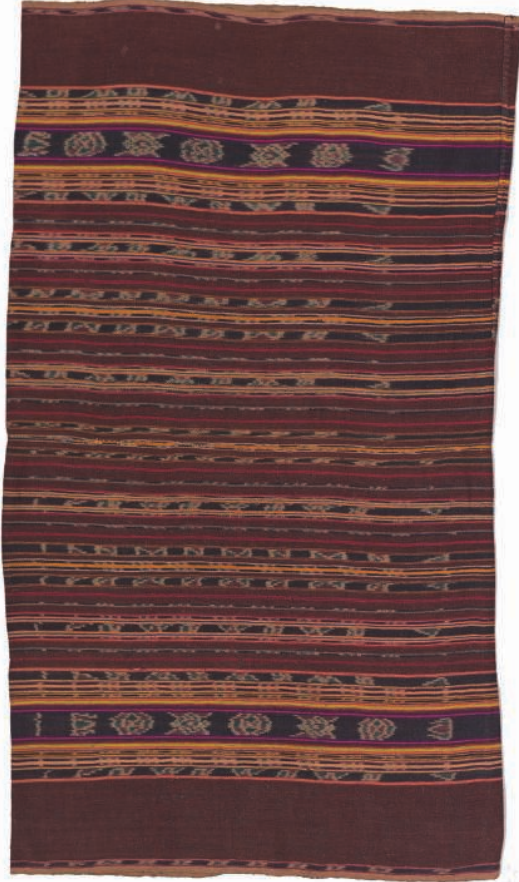

Fig. 14 - Tenapi Matang Karing of the Suku Uma Aring, Uma Pura (Photo by Linda S. McIntosh).

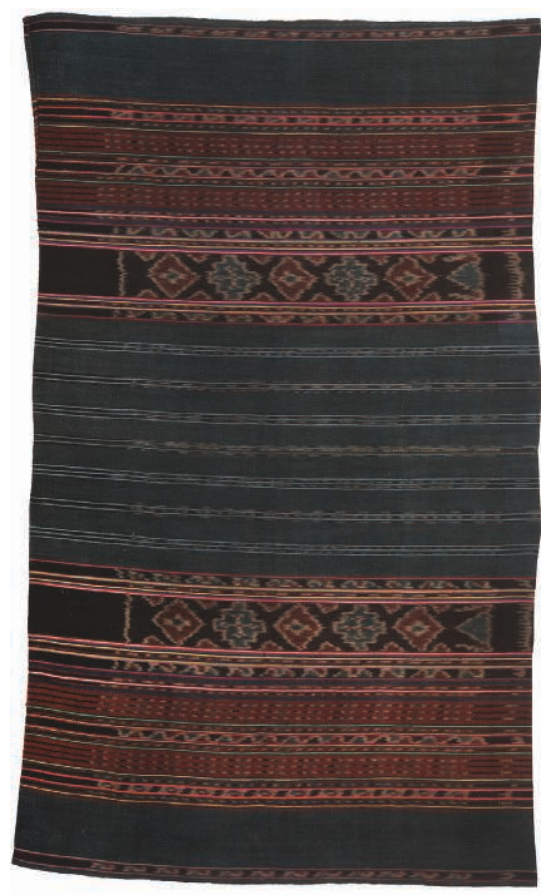

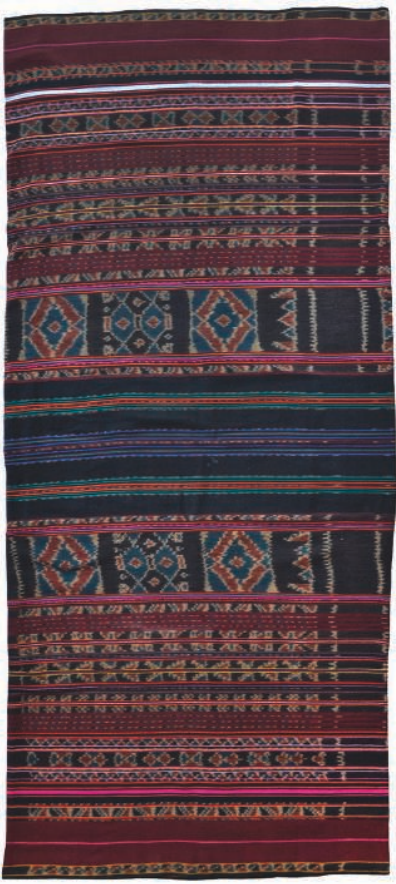

Fig 15 - Tenapi Bui'lihing Lanzia of the Suku Uma Wiluwalu Bawah, Uma Pura (Photo by Linda S. McIntosh).
Fig. 16 - Tenapi Bui'lihing or Builihing Bao Lolong of the Suku Uma Wiluwalu Atas, Uma Pura (Photo by Linda S. McIntosh). 


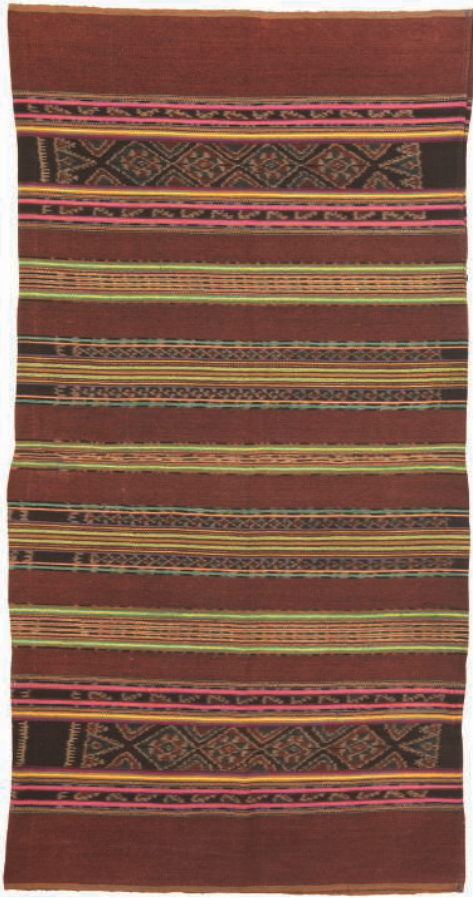

Fig. 17 - Tenapi Muko Tahakang of the Suku Uma Dengwahi, Uma Pura (Photo by Linda S. McIntosh).

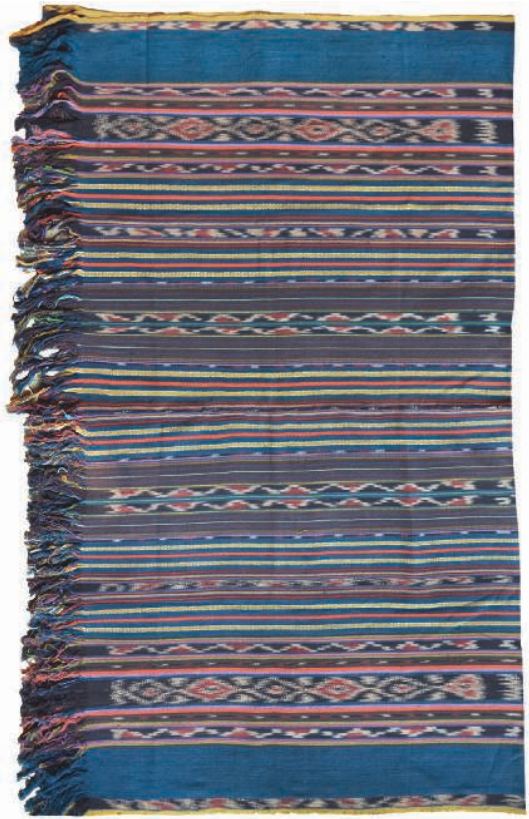

Fig. 19 - Tenapi Sinta Gala of the Suku Uma Biatabang, Uma Pura. A reproduction was produced since an old example could not be found (Photo by Linda S. McIntosh). 
Fig. 20 - Some traditional motifs decorating ceremonial tenapi and other Alorese textiles (Photo by Linda S. McIntosh)..
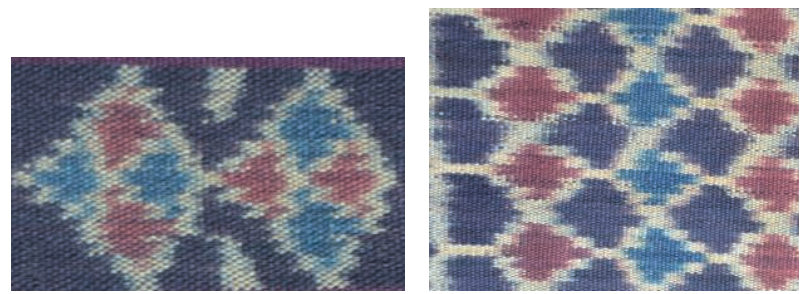

Fig 20a-Bao lolong or banyan tree Fig 20b - Bao lolong sambung leaf motif. A banyan tree is often or connecting banyan tree leaves found in a dolu, an elevated area in motif. This lattice design was a settlement composed of rocks and inspired by patterning decorating rammed earth where rituals are held. the central field of patola.
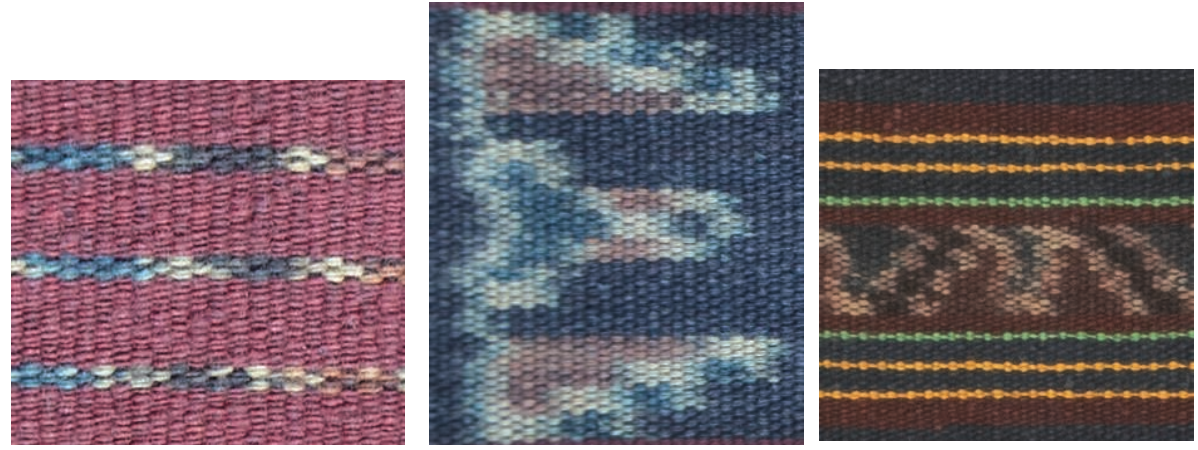

Fig 20d - Malu gilu or broken piper betel fruit motif. (The design is also called peku peku.)

Fig 20e - Ufe kotong or sea hare Fig 20f - Nura or a local type of motif. Collecting marine life such boat motif.

as sea hares and sea cucumbers is a traditional occupation of women from Uma Pura.

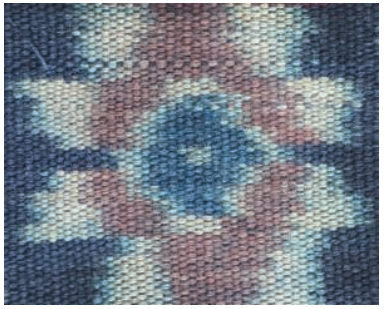

Fig 20c - Plinta or bursting kapok motif. When ripe kapok buds burst open, it signals the onset of the rainy season and farming in the agricultural cycle.
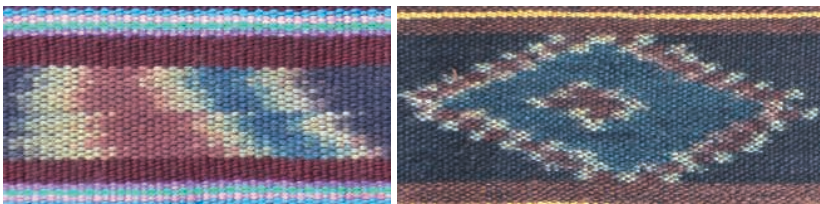

Fig 20g - Tapo lolong or coconut Fig 20h - Utam pei or tropical almond frond motif. motif.

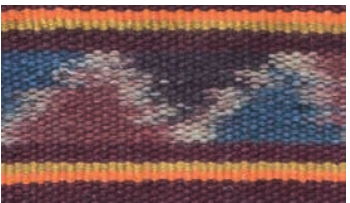

Fig 20i - Kago no-eking or intertwining bodies that is sometimes interpreted as an unified group or entity. 


\section{Plant Dyes in Alorese Language}

\section{Yellow Dyes}

Akar (Maclura cochinchinensis) - Cockspur thorn combined with alum produces a yellow dye.

Jarak merah (Jatropha gossypiifolia) - The leaves and stalks of the bellyache bush, also called physic nut, combined with hot water create a beige to light yellow-green colour. The weaver informants likened the colour to golden bamboo (Alorese kumanena) (figs. 23-24).

Kumo (Curcuma longa) - Chopped, fresh turmeric combined with fresh lime juice and rinds in simmering water forms a bright yellow dye (fig. 25). The addition of the juice of the kaffir lime (Citrus hystrix, Alorese muda keraking) creates a bright yellow colour, while regular or smooth-skinned limes (Citrus latifola or Citrus aurantifolia, Alorese muda mantalukung) produce a cloudy yellow colour (fig. 26). Fresh turmeric is preferred over dried roots. The addition of slaked lime powder or calcium hydroxide (Alorese $a p u$ ) changes the turmeric/lime juice dye bath to an orange colour (fig. 27).

Kewera or nangka depending on the Alorese dialect (Antocarpus heterophyllus) - Jackfruit tree heartwood creates a muddy yellow colour.

\section{Red Dyes}

Bota (Morinda citrifolia) - The weavers grow morinda in Alor Island. Finely ground, fresh roots combined with slaked lime powder or calcium hydroxide in room-temperature water produce different shades of pink and red (fig. 28). Weavers also use the dried outer bark of morinda roots to make a brown dye (fig. 29). Oil from candlenut (Aleurites moluccana) and ground symplocos leaves (Symplocos cochinchinensis, Alorese loba lolong) are required to create a colourfast dye. Resembling morinda dyeing in other parts of Indonesia, threads are soaked in candlenut oil and dried in the sun repeatedly before mordanting them with symplocos leaves. Some weaver informants such as Mama Sahari and Mama Admina of the Pante Laut Weaver's Cooperative stated that threads dyed with morinda must be dried in sunlight and not be exposed to moonlight. The yarns are covered at night because moonlight affects the uniformity of the dye adhering to the fibres. A few weavers experimented and placed morinda-dyed threads in the moonlight and attest that the exposure to moonlight results in unevenly dyed materials.

Ufang (Areca catechu) - Areca nut creates a red colour.

\section{Pink and Purple Dyes}

Kayu pen/hong/song (Caesalpinia sappan) - The supply of sappan wood originates from Matap, Southwest Alor, and Pantar Island. A handful of salt 
and fresh or dried wood shavings are combined in simmering water to produce a colourfast dye (fig. 30). Threads are dyed 3-5 times, depending on the desired shade of pink (fig. 31).

\section{Blue dye}

Taum (Indigofera tinctoria and other varieties) - In common with other parts of the world, indigo is dyed using a multi-stage process that begins with fermentation to produce the soluble, reduced form of indigo. Indigo grown on Alor Island is a seasonal dye (fig. 32). Weavers soak fresh leaves in water for approximately 24 hours and then remove the plant debris. A reducing agent, such as local palm alcohol, is combined with the solution to remove oxygen and allow the indigo molecule to become soluble in water. Then, weavers add slaked lime or calcium hydroxide powder (Alorese $a p u$ ) to the mixture, changing its $\mathrm{pH}$ to be more alkaline. The vat is ready to dye threads when it becomes yellowish-green colour. The yarns turn blue once they are removed from the vat and exposed to air, or when oxidation occurs. A light blue is a result if the threads are dyed once or twice. Multiple submersions are required to achieve a dark blue (fig. 33). Weavers dye and dry yarns repeatedly until reaching the desired shade.

Weavers in Uma Pura described on October 24, 2019, that when weavers create an indigo dye vat, men should not be present since the Alorese consider the power of indigo to colour threads can also weaken a man's potency. If a male touches the indigo dye or wet indigo-dyed yarns, he will lose his virility. If a woman is menstruating, she may assist in collecting and chopping indigo branches to make the dye vat, but she should not handle the mixing of the indigo dye or attempt to dye threads. Otherwise, the dye mixture will be weak, unable to produce a dark colour. Despite these taboos, indigo dyeing is carried out within the village rather than outside its borders.

\section{Tan and Brown Dyes}

Kebuka (Ziziphus mauritiana) - Jujube tree wood is used as a dye to create pinkish-tan to brown shades (figs. 34-35).

Bula (Lannea coromandelica) - The heartwood of the Indian ash tree is used to form a cinnamon brown colour (fig. 36). The addition of slaked lime powder to the simmering vat produces a lavender-pink shade (fig. 37).

Ipi (Intsia palembanica) - Borneo teak, is a dyestuff purchased by the weavers. The dye bath consists of simmering water and ground kayu ipi beginning with 4-5 tablespoons, to create a dark chocolate brown colour (fig 38). Threads are dyed 4-5 times to intensify the colour.

Tongke or bakau (Rhizophora mucronata) - Mangrove root bark (fig. 39) is combined with slaked lime or calcium hydroxide powder in simmering water to produce a red-orange to reddish-brown shade (fig. 40). 


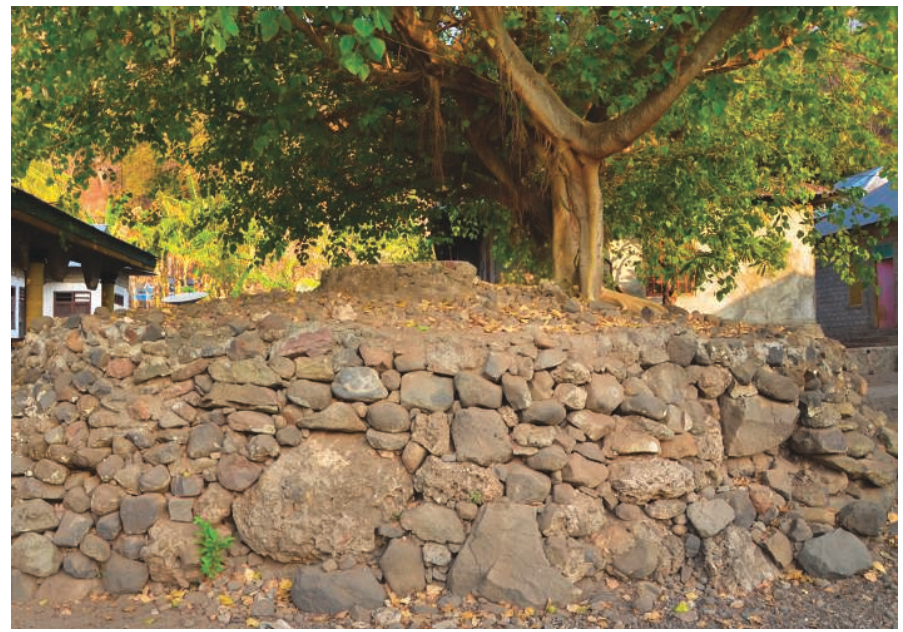

Fig. 21 - The dolu or ritual centre of Alor Besar, Northwest Alor District, Alor Regency. A banyan grows from its centre (Photo by Linda S. McIntosh).

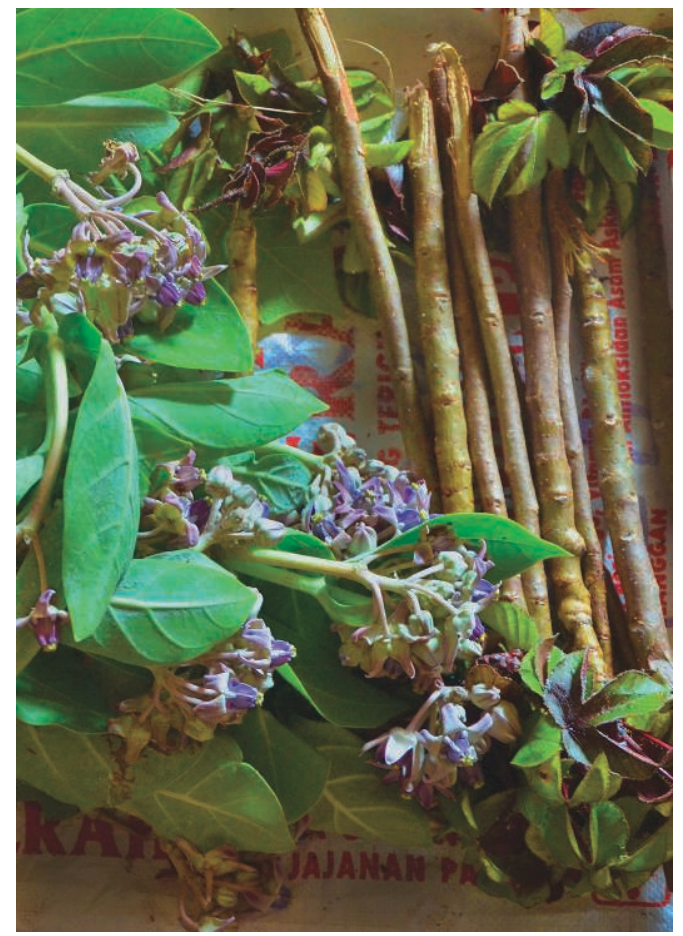

Fig. 22 - Some natural dyestuffs commonly used in Uma Pura: leaves and stalks of giant milkweed plants, left, and bellyache bush (Jatropha gossypiifolia), right (Photo by Linda S. McIntosh). 


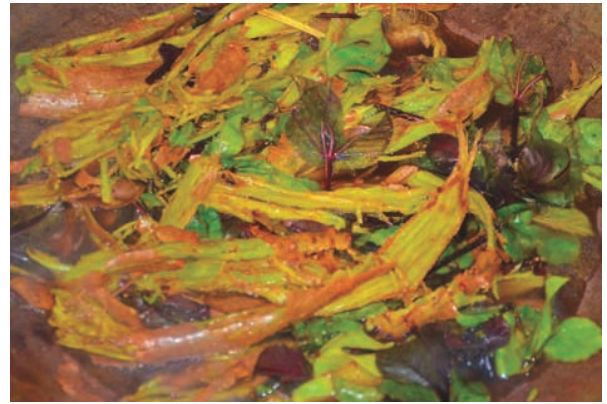

Fig. 23 - Dyeing cotton thread with bellyache bush (Jatropha gossypiifolia) or jarak (Photo by Linda S. McIntosh).

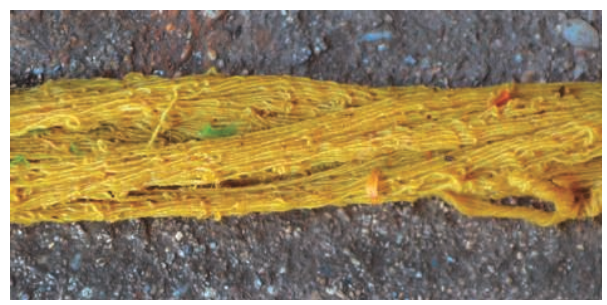

Fig. 24 - Bellyache bush-dyed cotton threads dyed creates a light-yellow hue the weaver informants call golden bamboo (Photo by Linda S. McIntosh).
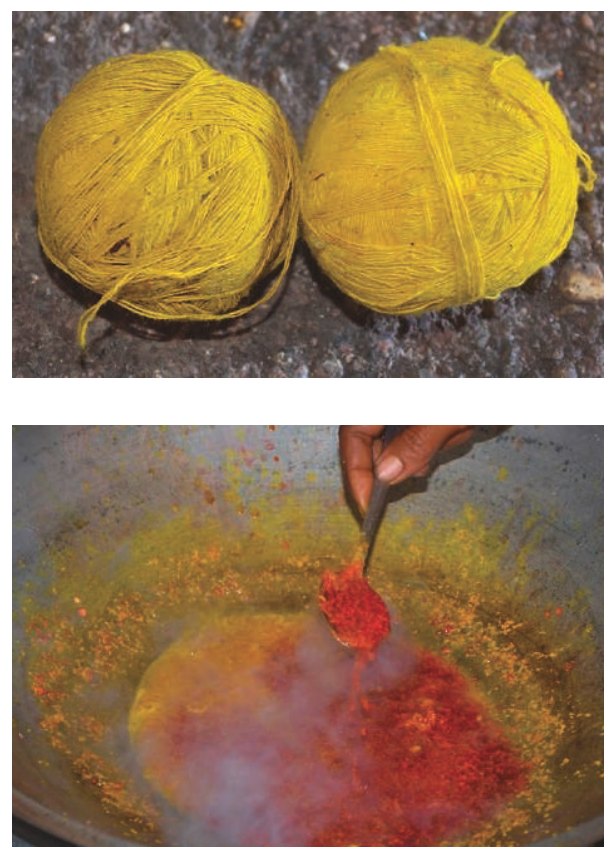

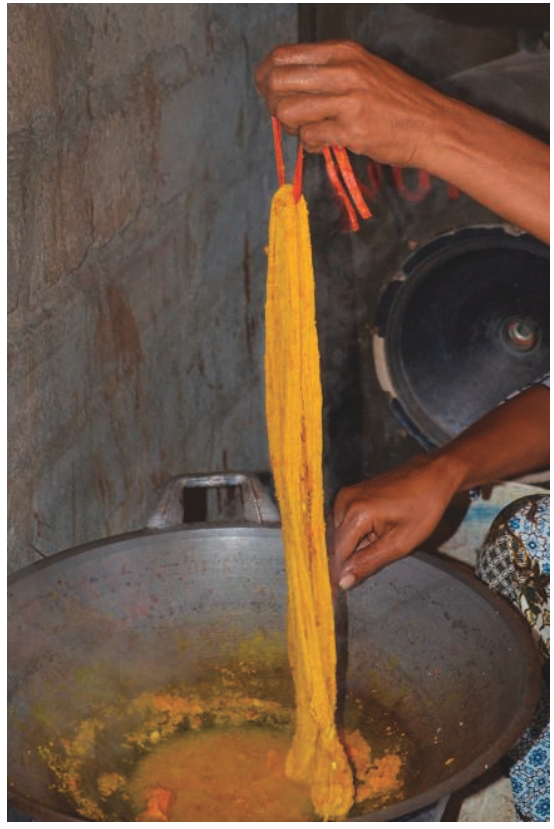

Fig. 25 - The weaver dyes cotton threads with fresh turmeric (Curcuma longa) or kumo with fresh lime juice in simmering water (Photo by Linda S. McIntosh).

Fig. 26 - A dye composed of fresh turmeric and smooth-skinned limes produces a cloudy yellow colour, left, while turmeric mixed with kaffir lime juice creates, a bright yellow, right (Photo by Linda S. McIntosh).

Fig. 27 - An Alorese weaver adds slaked lime powder to the turmeric and lime juice dye vat to produce orange (Photo by Linda S. McIntosh). 


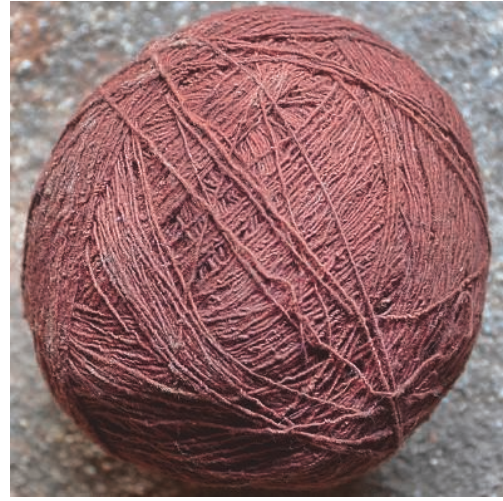

Fig. 28 - Cotton threads dyed with fresh morinda roots (Morinda citrifolia) or bota (Photo by Linda S. McIntosh).

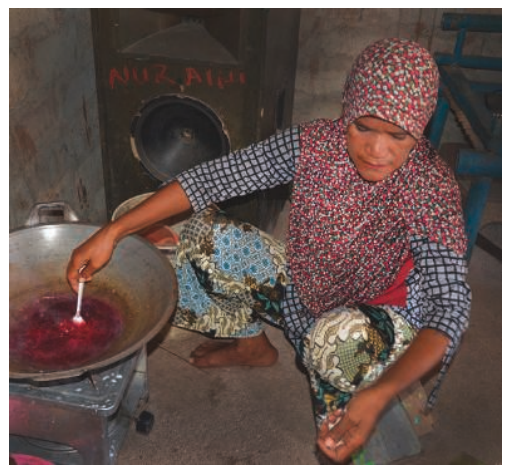

Fig. 30 - A weaver adds a handful of salt to a ground heartwood of the sappan tree (Caesalpinia sappan) simmering water (Photo by Linda S. McIntosh).

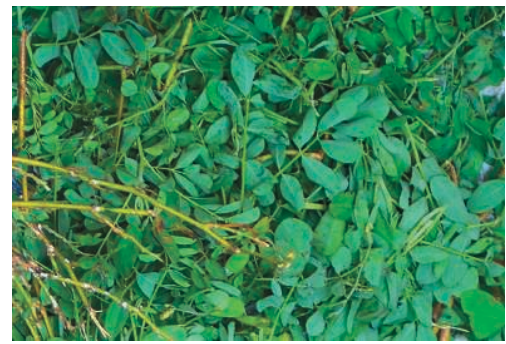

Fig. 32 - Fresh taum or indigo leaves (Indigofera tinctoria) for creating shades of blue (Photo by Linda S. McIntosh).

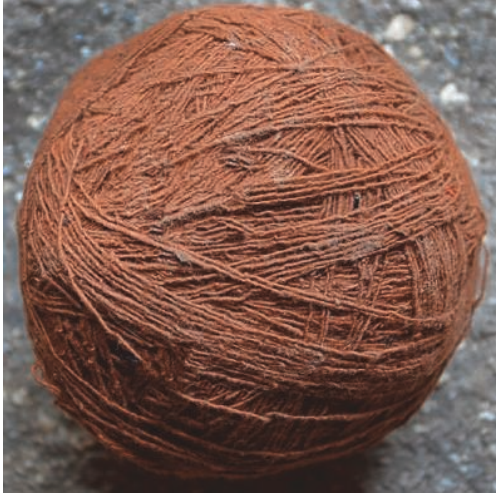

Fig. 29 - Cotton thread dyed with dried morinda roots. The cotton was oiled and then mordanted with an alum prior to dyeing (Photo by Linda S. McIntosh).

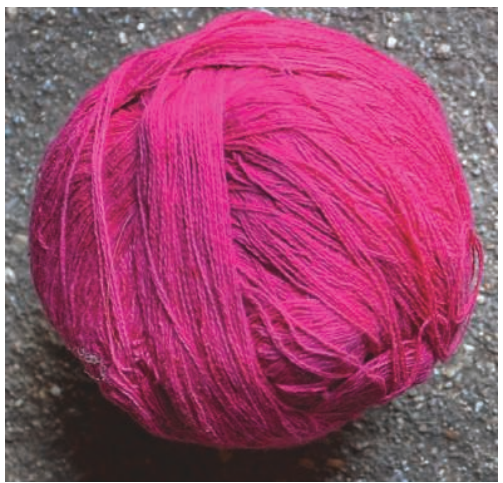

Fig. 31 - Sappan or pen, hong, or song wood-dyed cotton threads (Photo by Linda S. McIntosh).

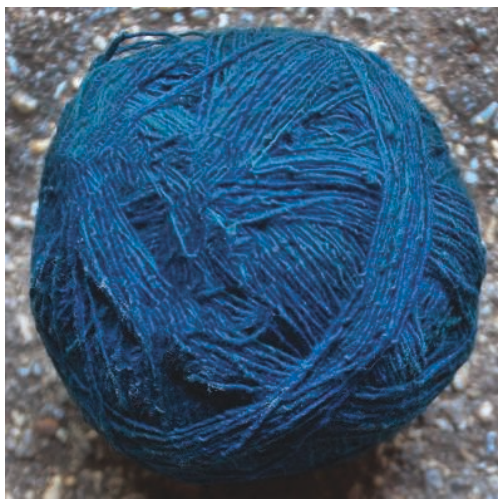

Fig. 33 - Cotton threads dyed in an indigo vat multiple times produces a deep blue shade (Photo by Linda S. McIntosh). 


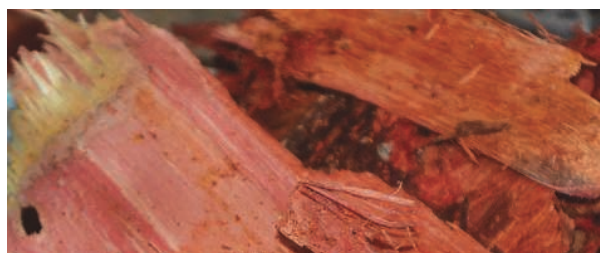

Fig. 34 - Wood of the Jujube tree (Ziziphus mauritiana) or kebuka (Photo by Linda S. McIntosh).

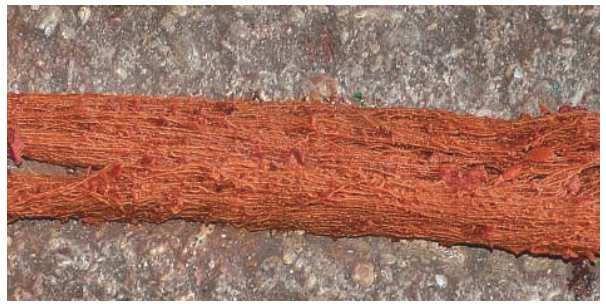

Fig. 36 - Indian ash tree (Lannea coromandelica) or bula produces a cinnamon brown colour (Photo by Linda S. McIntosh).

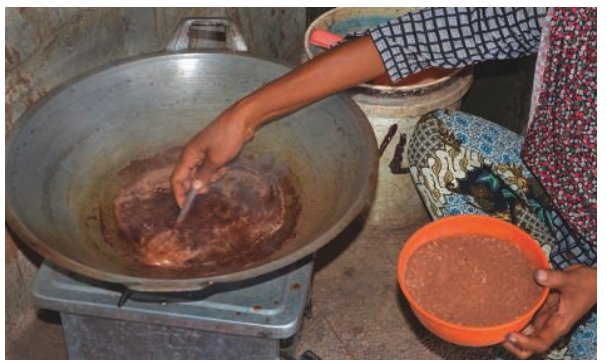

Fig. 38 - Adding ground ipi or Borneo teak wood (Intsia palembanica) to simmering water to dye threads dark brown (Photo by Linda S. McIntosh).

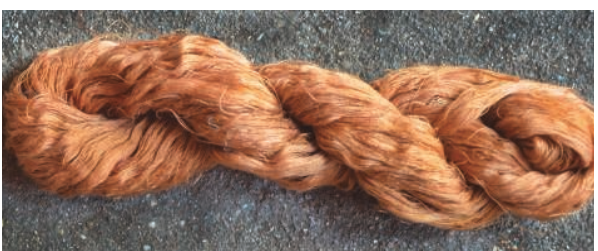

Fig. 35 - A jujube or kebuka wood dye vat creates a light pink tan to brown shades (Photo by Linda S. McIntosh).

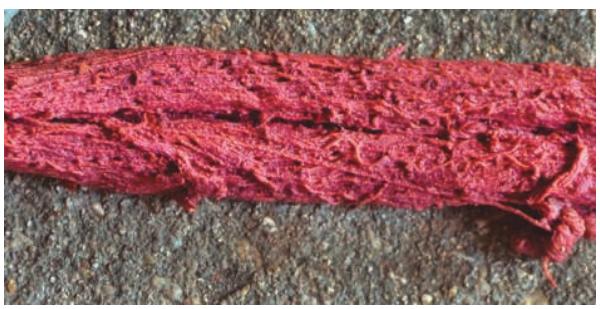

Fig. 37 - Threads dyed with an Indian ash or bula tree dye vat with the addition of slaked lime powder creates a lavender brown shade (Photo by Linda S. McIntosh).

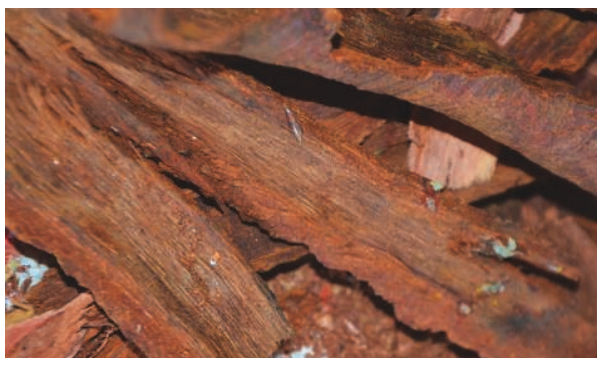

Fig. 39 - Dried root bark of the mangrove (Rhizophora mucronata) or tongke (Photo by Linda S. McIntosh).

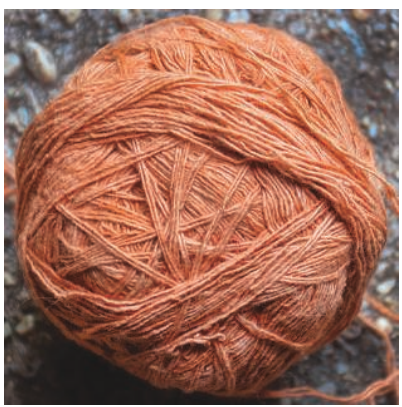

Fig. 40 - Dried mangrove root bark or tongke-dyed cotton threads (Photo by Linda S. McIntosh). 


\section{Green Dyes}

Keroko puhong (Calotropis gigantea) - Milkweed grows profusely on Ternate and other islands, and its leaves and stalks are also used as a dyestuff for light green. When leaves are combined with turmeric and candlenut in room temperature water, a yellow dye is created.

Ketapang (Terminalia catappa) - Tropical almond leaves form a light green while a black colour can be achieved from its bark and fruit. The wood makes a light yellow.

\section{Marine Life Dyes in Alorese Language}

Weavers have created other dyes using marine life such as sea hares, sea urchins, sea cucumbers, and sponges as the main ingredients (fig. 41). They manipulate the internal organs of echinoderms, a phylum of marine animals that includes sea cucumbers, to produce different shades of green. The use of a mordant was not observed when dyeing with the different types of marine life, and water was at room temperature rather than heated when processing these dyes.

Kula or sea sponges are sessile metazoans or multi-celled, immobile animals belonging to the phylum Porifera. Demospongiae is the largest class of this phylum and includes Spongiidae or the common bath sponges. The sponge diversity of Indonesia's seas is high although inadequately studied. Over 10,000 species are thought to exist worldwide, and approximately 800 have been recorded in Indonesia's seas. Coral reefs are the habitat of numerous species, and sponges are filter feeders eating plankton and algae as water passes through their bodies. They exhibit a range of colours depending on their food source, and their colouration is considered to protect against UV rays. Weavers use different coloured sponges, such as light blue, pink, yellow, dark-purple or black, to dye threads (fig. 42). Threads are kneaded with pieces of sponge in water to colour the fibres the same colour as the sponge (fig. 43).

\section{Purple, Grey, and Black Dyes}

Kenuna or squid ink creates a reddish dark brown-to-black colour, and a few weavers use squid ink as a cloth dye. The ink was used to draw on bark cloth or tapa or kapa in Hawaii, and ink from squid and cuttlefish has also been used for writing, drawing, and painting since Greco-Roman times (Krohn-Ching 1978: 13). The squid is a cephalopod, or a marine animal with a large head, belonging to the phylum Mollusca (sea hares are also part of this phylum). Cephalopod ink, generally composed of melanin, is generated in ink glands and stored in the ink sac, and squids release the liquid along with mucus as a defence mechanism.

Ufe kotong or the sea hare in general belongs to the genera Aplysia. The inks from sea hares created from the combination of two glands, one consisting of opaline and the other ink, contain aplysioviolin (APV) used to deter predators. 
APV is derived from red algal photosynthetic pigments that form part of the sea hare's diet, ${ }^{1}$ which are also used as natural food colourants and cosmetic dyes. $^{2}$ APV has served as a dye since antiquity. The colour of the sea hare ink varies depending on the sea hare's food choice, and Aplysia californica, Aplysia dactylomela, Aplysia oculifera, and Aplysia parvula consume red algae to produce purple ink. Weavers produce a purple or rose brown dye by removing the ink gland from the sea hare and massaging the ink into the yarns (fig. 44). Aplysia parvula (Alorese siput) produces more ink and, thus, dye than the other species.

Beragang or sea urchins are marine animals classified in the phylum Echinodermata. Several species live in Indonesian waters such as Diadema setosum and Diadema savignyi. Their habitat is also the coral reef, and they also feed on different coloured algae. The ink from sea urchins creates different shades of purple, but generally, a dark shade of purple is produced by those inhabiting the sea surrounding Ternate Island. Sea urchin ink was also used to draw on bark cloth or tapa or kapa in Hawaii. Dyeing with sea urchins resembles the colouring of threads with other kinds of marine life, by removing the ink gland and massaging the ink directly into threads.

Kula miteng or the seagrass Thalassia hemprichii that has turned red produces shades of grey. However, the government has forbidden foraging seagrass since it is the habitat of the dugong (Dugong dugon) and various fish and turtle species, and weavers of Uma Pura have ceased using it as to dye.

\section{Green Dye}

Nenas is the type of sea cucumber (Alorese menafe kotong, in general) used for dyeing. Sea cucumbers belong to the class Holothuroidea of the phylum Echinodermata. Some species reside in coral reefs, and others are bottom feeders, acquiring nutrients from algae, waste products, and tiny organisms on the seafloor. Weavers apply the internal organs of sea cucumbers to produce a green dye. Light green occurs after two submersions in the dye bath, while a dark army green is formed after dyeing the threads seven or more times (fig. 45).

\section{Contemporary Trends in Production of Alorese Textiles}

Government programs promoted the commercialisation of handwoven textile production in the last decades of the $20^{\text {th }}$ century. Bureaucrats and teachers are required to wear clothing made from locally woven textiles once a week, and another mandate also encourages students to wear this type of clothing weekly. Textiles for this market are not expensive and are generally composed of threads produced in factories. Weavers use synthetic dyes

1. Prince and Johnson 2013.

2. Solymosi et al. 2015. 
to apply warp ikat technique quickly. Presently, machine-spun threads and chemical dyes are readily available in the market, and many weavers use these materials for textile production. Access to these factory-produced materials has led to cloth in a rainbow of colours, including white, black, green, yellow, and pink, being woven instead of the primary shades of blue and red.

The diversification of the consumers of Alorese textiles includes national and international tourists and fashion designers from the national capital of Jakarta. Some of these consumers prefer natural materials such as handspun cotton and natural dyes. Weavers of Uma Pura, thus, have buyers for textiles dyed naturally with plants and marine life. Some experienced dyers, such as Mama Sahari Kamarin, president of the Pante Laut Weaver's Cooperative of Uma Pura Village, have been invited to teach natural dyeing to others in Indonesia, including Batak weavers of North Sumatra. However, these different consumers of the Alorese textiles often demand a colour range of natural dyes contrasting with the primary dyes of indigo and morinda.

Uma Pura weavers have also been encouraged to create new patterns via government programs and other external elements. These designs include realistic representations of trees, especially the banyan tree, and animals such as butterflies, fish, turtles, elephants, crabs, and other living creatures. Items from the social environment also inspire new or non-traditional motifs. Designs of mosques and traditional houses where rituals occur are produced using warp ikat technique.

The ongoing commercialisation of Uma Pura textile production is creating a decline in the quality and types of warp ikat motifs. The patterns have increased in size and become less detailed. The number of designs decorating one tenapi is also declining for the weaver to complete a weaving in a shorter amount of time. An increase in the size of the stripes is also occurring, emphasising on colour or the dyes used to produce a particular textile. The authors have requested some weavers to reproduce the traditional tenapi, especially ones signifying clan affiliation, but they were reluctant to take the order even for a high price. Tying intricate warp ikat patterns takes time. Dyeing threads with indigo and morinda to create the dark shades used to create the ceremonial garments traditionally also requires redyeing the threads multiple times. Additional time is, thus, needed to complete a traditionally designed and coloured textile. 


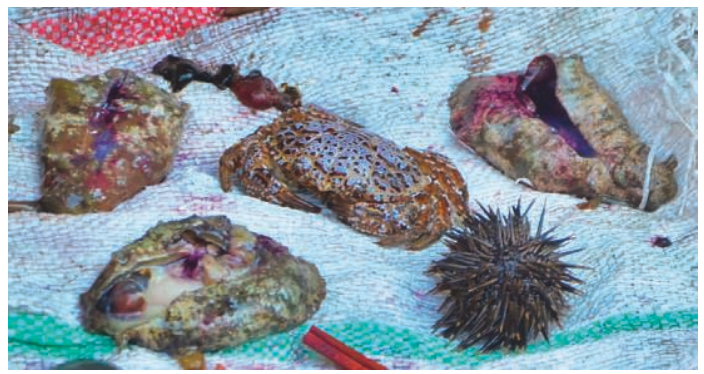

Fig. 41 - The inks of sea urchins, beragang, and sea hares, ufe kotong, are some of the marine life dyes of the Alorese (Photo by Linda S. McIntosh).

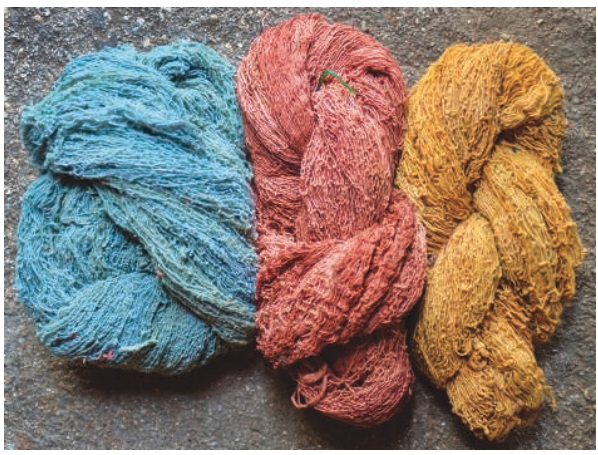

Fig. 42 - Different-coloured dyed threads from various sea sponges or kula (Photo by Linda S. McIntosh).

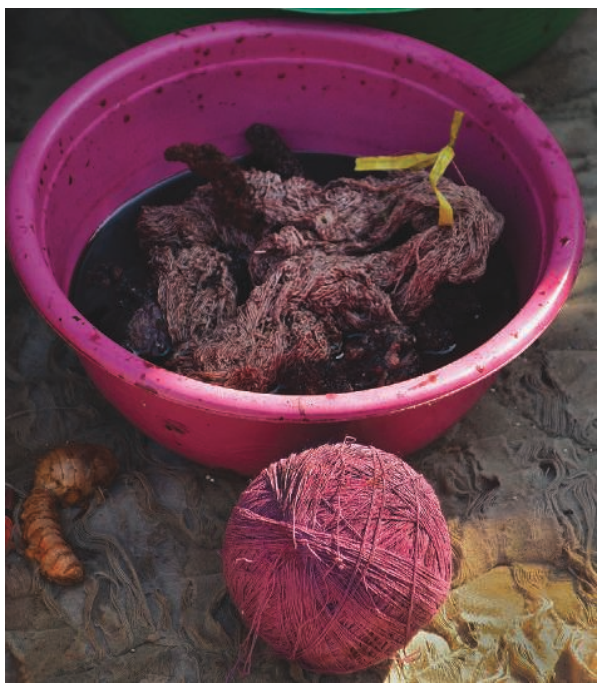

Fig. 44 - Dyeing threads with ink and opaline for sea hares or ufe kotong. Dried threads dyed with sea hare ink are in the foreground (Photo by Linda S. McIntosh).

Archipel 102, Paris, 2021

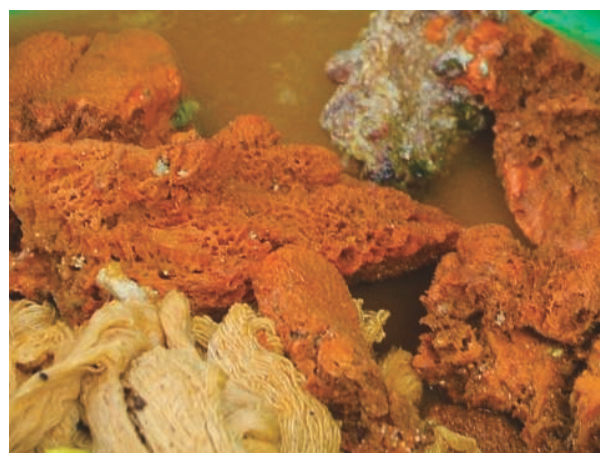

Fig. 43 - Dyeing threads with fresh orange-coloured sea sponge and water produces a light orange shade (see Fig. 22), far right) (Photo by Linda S. McIntosh).

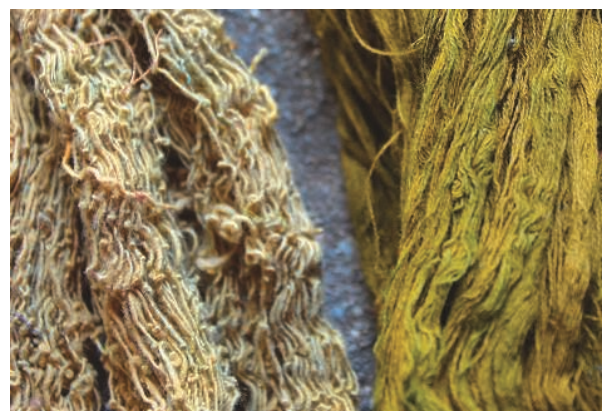

Fig. 45 - Threads dyed with the internal organs of sea cucumbers or nenas. Light green is achieved by dyeing threads a few times, left, while a dark green is produced by dyeing materials seven or more times, right (Photo by Linda S. McIntosh). 


\section{Conclusion}

Warp ikat textile production and natural dyeing continue to thrive in Uma Pura, Alor Regency, Indonesia, as a niche occupation for women when it has declined in other Alorese settlements on Alor and Pantar islands. Weaving in other Alorese villages was almost extinct until the government intervened in the 1970s (Gomang 1993: 108). However, textile production of Uma Pura has experienced change, especially in the last fifty years. Government programs and other external factors such as tourism affected what women wove. Synthetic threads and machine-spun cotton have replaced most of the handspun cotton and milkweed threads the weavers previously made, and chemical dyes are used along with natural ones. The threads and chemical dyes purchased in the market come in various colours, and weavers are producing textiles in colourways beyond the traditional indigo blue and morinda red that dominate traditional weavings. The commercialisation of Alorese textiles requires raw materials for dozens of textiles to be woven by one woman annually, leading to a reliance on threads that are sold in the local markets instead of cultivating and processing the materials in or near the village.

Textile production continues for personal and household consumption, including ceremonial garments indicating patrilineal clan affiliation, and for local trade with other Alorese and non-weaving groups belonging to the AlorPantar branch of the Trans-New Guinea ethnolinguistic family that compose the majority of the regency's population. However, the consumers of Alorese textiles have expanded to include other people belonging to other ethnic groups from different parts of the country and international clients. The uses of the weavings are changing due to the diversity of consumers. Alorese textiles of Uma Pura are tailored into school and government employee uniforms and become part of contemporary fashions. Examples serve as souvenirs for domestic and international tourists.

The diversification of textiles produced by weavers of Uma Pura has led to the reduction of time and resources to traditional weavings such as ceremonial tenapi representing patrilineal clan affiliation. A woman may make one for herself and her immediate family members in a decade or even a lifetime. The number of weavers with the skills and information regarding the design format and motifs composing these traditional garments is declining. Some women, especially new weavers, cannot describe the characteristics of some tenapi. The names of traditional motifs have not changed yet, but it is possible for change to occur or for some designs to be lost. Preserving this knowledge now will serve as a resource for researchers and members of Uma Pura and other communities to use in case some of these traditions disappear.

The warp ikat motif repertoire of Uma Pura has also grown as commercialisation increased. Weavers continue to find inspiration for new designs from their natural and social environments. Many of these patterns 
are figurative, depicting fish and other marine life and important religious structures such as mosques and ritual houses. Traditional motifs or ones that decorated textiles mid-20 $0^{\text {th }}$ century and earlier consist of geometric shapes and undulating lines symbolic of items significant to the Uma Pura community. Both categories of patterns decorate contemporary production.

Emilie Wellfelt noted that both the individual and group identity of the people of Uma Pura are embedded in membership in one of the settlement's eight patrilineages or $s u k u$. The textiles produced in this community, especially tenapi of Uma Pura's patrilineages, are an expression of clan affiliation. Although these tenapi differentiate members of lineage from another, the textiles also unite members of the community. These warp ikat-decorated weavings also serve as symbols of Alorese culture, unifying members of Uma Pura with members of the same group living in coastal areas of northwest Alor and west and central Pantar islands. The warp ikat textiles have also become symbols of Alor Regency's cultural heritage, and the government has registered geographic indication for Alorese warp ikat as Alor textiles in 2019 (ASEAN GI Database, accessed April 27, 2021).

\section{References}

Andaya, Leonard. "The Social Value of Elephant Tusks and Bronze Drums among Certain Societies in Eastern Indonesia.” Bijdragen tot de Taal-, Land- en Volkenkunde 172:1 (2016), 66-89.

ASEAN GI Database. IDGI0000000000076, http://www.asean-gidatabase.org/gidatabase/, accessed April 20, 2021.

Barnes, Ruth. The Ikat Textiles of Lamalera: A Study of an Eastern Indonesian Weaving Tradition. Leiden: Brill, 1989.

Barnes, Ruth. Ostindonesian im 20. Jahrhundert: Auf den Spuren der Sammlung Ernst Vatter. Frankfurt: Museum der Weltkulturen.

Central Bureau of Statistics of Alor Regency, Alor Barat Laut District in Figures 2020. Kalabahi: Central Bureau of Statistics of Alor Regency, 2020.

Du Bois, Cora. The People of Alor, a Social-psychological Study of an East Indian Island. Minneapolis, MN: University of Minnesota Press, 1944.

Fricke, Hanna, and Marian Klamer. "Reconstructing Linguistic and Social Histories of the Lamaholot Region." $7^{\text {th }}$ East Nusantara Conference, Kupang, 14-15 May 2018.

Gomang, Syarifuddin R. "The People of Alor and their Alliances in Eastern Indonesia: a study of Political Sociology." Master of Arts (Hons) thesis, Department of Sociology, Wollongong University, 1993.

Hamilton, Roy W. "Textiles and Identity in Eastern Indonesia." In Five Centuries of Indonesian Textiles, edited by Ruth Barnes and Mary Hunt Kahlenberg. New York: Prestel, 2010, 300-313.

Hägerdal, Hans. "Cannibals and Pedlars." Indonesia and the Malay World 38:111 (2010), 217-246.

Hägerdal, Hans. "Van Galen's memorandum on the Alor Islands in 1946. An annotated translation with an introduction. Part 2." HumaNetten 27 (2011), 53-96.

Hoopen, Peter ten. Woven Languages: Indonesian Ikat Textiles from the Peter ten Hoopen. Collection: Lisbon: Mueso do Oriente, 2014. 
Hoopen, Peter ten. Ikat Textiles of the Indonesian Archipelago. Hong Kong: Hong Kong University Press, 2018.

Howard, Michael C. A World between the Warps: Southeast Asia's Supplementary Warp Textiles: Studies in Material Cultures of Southeast Asia No. 12. Bangkok: White Lotus, 2008.

Howard, Michael C. From Dashes to Dragons: The Ikat Patterned Textiles of Southeast Asia. Studies in Material Cultures of Southeast Asia No. 14. Bangkok: White Lotus, 2010.

Kaiping, Gereon A., Owen Edwards, and Marian Klamer (eds.). 2019. LexiRumah 3.0.0. Leiden: Leiden University Centre for Linguistics.

Khan Majlis, Brigitte. Woven Messages: Indonesian Textile Tradition in Course of Time. Hildeshiem: Roemer Museum, 1991.

Klamer, Marian. A Short Grammar of Alorese (Austronesian). Munich: Lincom Europa, 2011.

Klamer, Marian. "Papuan-Austronesian language contact: Alorese from an Areal Perspective." In Melanesian languages on the edge of Asia: Challenges for the 21st century. Language Documentation \& Conservation Special Publication 5, edited by Nicholas Evans and Marian Klamer. Honolulu: University of Hawai'i Press, 2012, 72-108.

Krohn-Ching, Val Freiling. Dyes of Old Hawaii. Honolulu: University of Hawaii, 1978.

McIntosh, Linda S., and Yulianti Peni. www.alortextiles.org, 2020.

McIntosh, Linda S. and Yulianti Peni. Textiles of Alor. Kalabahi, Indonesia: Museum 1000 Moko, 2020.

Peni, Yulianti, and Linda S. McIntosh. "Rarely-Documented Textiles: Tenapi of Uma Pura Village, Ternate Isle, Alor Regency, Indonesia.” Textiles Asia 12:1 (May 2020), 6-14.

Prince, Jeffery S., and Paul Micah Johnson, "Role of the Digestive Gland in Ink Production in Four Species of Sea Hares: An Ultrastructural Comparison." Journal of Marine Sciences 2013, 1-5. Article ID 209496, http://dx.doi.org/10.1155/2013/209496

Rema Nyoman, and Hedwi Prihatmoko, "Potensi Arkeologi di Pulau Alor (Archaeological Potentials in Alor Island)." Kalpataru Majalah Arkeologi 25:2 (November 2016), 103-116.

Richardson, David, and Sue Richardson. http://www.asiantextilestudies.com, 2019.

Rodemeier, Susanne. "Islam in the Protestant Environment of Alor and Pantar Islands." Indonesia and the Malay World 38:110 (2010), 27-42.

Solymosi, Katalin, Norbert Latruffe, Annick Maurant-Menceau, and Benoit Schoefs. "Food Colour Additives of Natural Origin." In Colour Additives for Food and Beverages, edited by Michael J. Scotter. Cambridge: Woodhead Publishing, 2015, 3-34.

Vatter, Ernst. Ata Kiwan: Unbekannte Bergvolker im Tropischen Holland. Leipzig: Bibliographisches Institute, 1932.

Wellfelt, Emilie "Diversity and Shared Identity: A case study of interreligious relations in Alor, Indonesia." Master's thesis, Goteberg University, 2007.

Wellfelt, Emilie. "The Secrets of Alorese 'Silk' yarn: Kolon susu, triangle trade and underwater women in Eastern Indonesia." In Textile Society of America $14^{\text {th }}$ Biennial Symposium Proceedings: New Directions: Examining the Past, Creating New Futures. Los Angeles, 10-14 September 2014.

Wellfelt, Emilie. "Historyscapes in Alor: Approaching indigenous history in Eastern Indonesia." PhD dissertation, Linnaeus University, 2016. 
